http://dx.doi.org/10.1007/s11356-012-1287-0

(c) Springer-Verlag Berlin Heidelberg 2012

The original publication is available at http://www.springerlink.com

\title{
Histopathological lesions and DNA adducts in the liver of European flounder (Platichthys flesus) collected in the Seine estuary versus two reference estuarine systems on the French Atlantic coast
}

\author{
Jérôme Cachot ${ }^{1}$, Yan Cherel ${ }^{2}$, Thibaut Larcher ${ }^{2}$, Annie Pfohl-Leszkowicz ${ }^{3}$, Jean Laroche ${ }^{4}$, \\ Louis Quiniou ${ }^{4}$, Jocelyne Morin, ${ }^{5}$ Julien Schmitz ${ }^{6}$, Thierry Burgeot ${ }^{7}$, Didier Pottier ${ }^{8}$
}

\author{
${ }^{1}$ Univ. Bordeaux, EPOC UMR 5805, LPTC Group, Avenue des Facultés, 33405, Talence, France \\ 2 INRA, UMR 703, Oniris, La Chantrerie, 44300, Nantes, France \\ 3 Univ. Toulouse, Laboratoire de Génie Chimique, UMR CNRS/INPT/UPS 5503, INP/ENSA Toulouse, 1 Avenue \\ Agrobiopole, 31326, Castanet-Tolosan, France \\ ${ }_{4}$ Université de Brest, UMR 6539, LEMAR, Institut Universitaire Européen de la Mer, 29280, Plouzané, France \\ ${ }^{5}$ Ifremer, Laboratoire Ressources Halieutiques, Ave du Général de Gaulle, 14520, Port-en-Bessin, France \\ ${ }^{6}$ Institut Français du Pétrole, 1-4 Avenue de Bois-Préau, 92852, Rueil-Malmaison Cedex, France \\ 7 Ifremer Nantes, Département Polluants Chimiques, Rue de l'lle d'Yeu, 44311, Nantes Cedex, France \\ ${ }^{8}$ Université de Caen Basse-Normandie, UR ABTE EA 4651, Centre François Baclesse, 3 Avenue Général Harris, \\ 14000, Caen, France
}

*: Corresponding author : Jérôme Cachot, email address : j.cachot@epoc.u-bordeaux1.fr

\begin{abstract}
:
An epidemiological survey was conducted in the Seine estuary and in two smaller and relatively preserved estuaries on the French Atlantic coast in order to estimate the occurrence of liver lesions in European flounder, Platichthys flesus, and also to seek putative risk factors for the recorded pathologies. Four hundred and seventy-eight fish of both sexes and of different size ranges were sampled in the three studied areas, 338 of which in the Seine estuary. All fish were examined for histopathological liver lesions, while DNA adducts and otoliths were analyzed on a subsample. Five categories of hepatic lesions were recorded with the following prevalence for the Seine estuary: $36.7 \%$ inflammations, $8 \%$ parasites (mainly encysted nematodes), $6.5 \%$ foci of cellular alteration (FCA), $5.3 \%$ foci of necrosis or regeneration (FNR), and $1.5 \%$ tumors. Inflammation occurrence increased according to age, contrary to parasitic infestations and FCA which were more prevalent in young fish, notably those of $<1$ year old (group 0 ). Tumors were only observed in females of more than two winters. Females exhibited a higher prevalence of tumors $(3.0 \%)$ and FCA $(6.5 \%)$ than males ( 0 and $2.6 \%$, respectively). Parasitic and infectious lesions and FNR were equally distributed in males and females. The prevalence of FNR was also shown to vary according to sampling season, with significantly more occurrences of liver necrosis in the fish collected in summer than in spring. Spatial differences were observed with a higher occurrence of encysted parasites in flounders from the upper Seine estuary, while inflammations predominated in flounders living downstream. Temporal trends were also noted, with an increased prevalence of parasitic infestations, inflammations, and FCA in the 2002-2003 period in comparison to the 1996-1997 one. The three flounder populations from
\end{abstract}


the Seine estuary (Normandy), Ster estuary (Brittany), and Bay of Veys (Normandy) showed different spectra of hepatic lesions. Flounders from the Bay of Veys had relatively few liver lesions as compared to flounders from the two other estuaries. Flounders from the Ster estuary exhibited the highest prevalence of parasites (37.2\%) and inflammations (51.1\%). Finally, FCA and liver tumors occurred at very similar levels in both flounder populations from the Seine and the Ster estuaries. Group 0 flounders inhabiting the upper Seine estuary were more prone to parasitic and pre-neoplastic hepatic lesions and had higher levels of liver DNA adducts than the older ones living downstream. It was postulated that group 0 European flounders may serve as valuable bioindicators for assessing the quality of estuarine waters and the health status of euryhaline fish populations.

Keywords: Epidemiological study ; European flounder ; Seine estuary ; Liver histopathology ; Necrosis ; FCA ; Tumors ; Inflammations ; Parasites ; DNA adducts ; Pollution

\author{
Abbreviations: \\ OSPAR: Oslo-Paris convention on the protection of the marine environment of the North-East Atlantic. \\ DRZ: diagonal radioactive zone. \\ EPCV: European College of Veterinary Pathologists
}

\title{
1. Introduction
}

Estuarine and coastal marine areas play a crucial ecological role as nursery and/or feeding grounds for a large variety of aquatic species, notably fish (Beck et al. 2001). Since nearly $60 \%$ of the human worldwide population lives and works within 100 miles of a coast (Hinrichsen 1998), these areas are even more impacted by human activities and, particularly, by chemicals. It is now currently accepted that sediments from estuaries and coastal areas are major reservoirs for a large variety of persistent organic or inorganic pollutants and secondary 
74 sources of pollution for aquatic ecosystems (Harris et al., 1996). An increase in the occurrence 75 of toxicopathic lesions and/or infectious or parasitic diseases in aquatic organisms chronically

76 exposed to pollutants has extensively been reviewed in recent years (Harmon and Wiley, 2010; Mearns et al., 2011). Increased susceptibility to pathologies can directly or indirectly impair the survival or biotic performances of individual organisms which, in turn, can affect the abundance, age structure, genetic diversity, and the reproduction of wild populations (Marchand et al., 2004; Benejam et al., 2010; Brooks et al., 2012).

The liver of vertebrates, including fish, is the main target for toxicants because of its high vascularization, its high lipid content and its role in the organic xenobiotic biotransformation and metabolism of sex hormones (Hinton et al., 2001). It has been shown that fish exposure to organic and metallic pollutants can lead to a wide range of toxicopathic lesions, including tumors, FCA (foci of cellular alteration) and several non-neoplastic liver lesions (Hinton et al., 2001). In the field, a strong relationship was reported between toxicopathic liver lesions and environmental contamination by persistent organic pollutants including $\mathrm{PAH}$ and organochlorinated hydrocarbons (Myers et al., 1998; Harshbarger and Clark, 1990; Myers et al., 2003). For all these reasons, toxicopathic liver lesions in fish liver are considered as sensitive and integrative biomarkers of pollutant exposure (Hinton et al., 2001) and their integration in a pollution monitoring program is now recommended by the OSPAR international organization (SGIMC, 2011).

The European flounder Platichthys flesus (L.) is a coastal and estuarine flatfish species which is widespread along the European coast, in the North Sea, the Atlantic Ocean and the Mediterranean Sea. Because of their benthic way of life, their bottom-feeding behavior and their relative longevity, flounders are particularly exposed to sediment-trapped pollutants. In addition, this species has been recommended by OSPAR for pollution monitoring in the North-East Atlantic. 
Several epidemiological studies focusing on liver pathologies in the European Flounder have

100 already been conducted in the North Sea and the Baltic Sea along the British, German and

101 Dutch coasts (Bogovski et al., 1999; Vethaak, 1992; Koehler, 2004; Vethaak et Wester, 1996;

102 Stentiford et al., 2003; Lang et al., 2006). But no or little data is available for the French

103 Atlantic coast. Furthermore, risk factors for certain liver lesions are not totally well-

104 understood and need further investigation.

105 In the present study, flounders were collected on the French Atlantic coast, in three different

106 estuaries having specific features in terms of size, hydrological conditions, human pressures

107 and water quality.

108 The Seine estuary is a large $\left(50 \mathrm{~km}^{2}\right)$, man-altered, macrotidal ecosystem on the French

109 Atlantic coast. The Seine River catchment covers about $79,000 \mathrm{~km}^{2}$ and is one of the most

110 urbanized and industrialized area in France with about $25 \%$ of the metropolitan population

111 (16 million inhabitants), $40 \%$ of the national economic activity and $30 \%$ of the national

112 agricultural activity. Due to the high pollutant inputs and a relatively low water flow (250 to

$113900 \mathrm{~mm}^{3} / \mathrm{s}$ ), PAHs and PCBs are currently detected at high levels in sediments (Cachot et al.,

114 2006), suspended matters (Cailleaud et al., 2007) and biota (Minier et al., 2006; Rocher et al.,

115 2006; Cailleaud et al., 2007). Furthermore, sediments from the upper Seine estuary were

116 shown to contain potent mutagenic and carcinogenic pollutants (Cachot et al., 2006) and

117 adverse health effects were reported in various invertebrates (Minier et al., 2006; Rocher et

118 al., 2006; Cailleaud et al., 2009) and fish species (Marchand et al., 2004; Gilliers et al., 2006;

119 Cachot et al., 2007; Amara et al., 2009).

120 The Bay of Veys is a large and shallow estuary of about $37 \mathrm{~km}^{2}$ located in the western part of 121 the Seine bay (east coast of Cotentin). Three main rivers including the Douve, the Taute and 122 the Vire are connected to this bay. The global river catchment of $3,500 \mathrm{~km}^{2}$ is poorly 
123

124 and dairy farming).

125 The Ster of Lesconil estuary is a small $\left(0.36 \mathrm{~km}^{2}\right)$ and pristine area located in Brittany with a 126 water catchment of about $100 \mathrm{~km}^{2}$. This river receives reduced domestic and agricultural 127 inputs and no industrial waste, and the levels of organic pollutants and metals currently found 128 in mussels and European flounders are low (Marchand et al., 2003; 2004).

129 The main objective of the present work is to make a first survey of liver pathologies and DNA 130 adduct levels in feral European flounders from these three contrasted estuaries. In addition, 131 this study aims at analyzing, for each of the various flounder liver pathologies, the putative 132 risk factors including biotic traits (age and sex) and abiotic parameters such as localization, 133 season and year of collection.

134

135

136

137

138

\section{Materials and Methods}

\subsection{Sampling sites}

The epidemiological survey was conducted in three estuaries along the French Atlantic coast: the Seine estuary (Normandy, France), the Bay of Veys (Normandy, France) and the Ster of Lesconil estuary (Brittany, France) (Figure 1A).

The Seine estuary extends over $170 \mathrm{~km}$ from Poses to Le Havre (Cap de la Hève). Three distinct areas can be distinguished within the Seine estuary (Figure 1B): the upper Seine estuary from Poses (upstream limit of the dynamic tide) to Caudebec which is the fresh water part of the estuary, the middle Seine estuary from Caudebec to Honfleur with mesohaline water, and the lower Seine estuary from Honfleur to the Seine Bay characterized by salt water and a high tidal range. A fourth area, named Antifer, localized in the Eastern part of the Seine 
147 bay along the Pays de Caux but under the direct influence of the Seine river plume was also 148 sampled (Figure 1B).

149

150

\subsection{Fish sampling and liver collection}

151 Juvenile and adult European flounders (Platichthys flesus, L.) of both sexes were collected by

152 trawling or netting in the course of 15 fishing campaigns between April 1996 and May 2004

153 (Table 1). Immediately after sampling, alive fish were transferred to tanks filled with

154 recirculated water prior to dissection. Amongst the 1505 captured fish, 478 fish were

155 randomly selected (the first twenty individuals for each sampled sites or all the captured fish

156 if less than twenty) for liver histopathological analysis. The fish had their spinal cord cut and

157 abdominal cavity carefully opened with dissecting scissors, in order to have the integrity of

158 their internal organs preserved. The fish was sized (total body length), sex was determined,

159 and the biggest otolith (the sagittal) was recovered from randomly selected fish for age

160 determination. The whole liver of small fish (up to $110 \mathrm{~mm}$ in length) was sampled for

161 histological examination, while for bigger individuals, $1 \mathrm{~cm}^{3}$ slice encompassing the whole

162 tissue thickness and width was collected using clean razor blades. The liver samples were 163 immediately fixed in $10 \%$ formalin buffer solutions. DNA adducts were measured in the liver

164 of flounders collected in the Seine estuary in September and October 1996 and in the Bay of

165 Veys in April 1997. A small piece of liver of about $1 \mathrm{~cm}^{3}$ was recovered from 10 to 15 166 individual fish of both genders and within the same size range. Immediately after collection, 167 liver samples were pooled in a clean DNase-free microtube and deep-frozen in liquid 168 nitrogen. Samples were then stored at $-80^{\circ} \mathrm{C}$ prior to analysis.

169

170

\subsection{Age determination}


171 The biggest otolith (the sagittal) was removed from 87 randomly selected fish of different size

172 and sex which had been caught in the Seine estuary. Otoliths were immersed in water and

173 examined with a stereomicroscope (Leica Wild M8) under transmitted light. Translucent

174 annuli corresponding to winter periods were counted.

175

\section{$176 \quad 2.4 \quad$ Liver histopathology}

177 Formalin-fixed tissues were dehydrated by transferring them through a series of alcohols of 178 increasing concentrations $\left(80 \%, 2 * 1\right.$ hour, $35^{\circ} \mathrm{C}, 2$ times; $95 \%, 2 * 1$ hour, $35^{\circ} \mathrm{C}, 2$ times $)$ up to

$179100 \%$ alcohol ( $4 * 1$ hour, 4 times). Next, they were placed into methylcyclohexan which is 180 miscible with both $100 \%$ alcohol and paraffin (methylcyclohexan, $3 * 1$ hour, $35^{\circ} \mathrm{C}, 3$ times).

181 Then they were put into melted paraffin $\left(3^{*} 1\right.$ hour, $58^{\circ} \mathrm{C}, 3$ times). All these operations were 182 performed using an Automat Tissue-Tek VIP 3000. The samples were then embedded in 183 paraffin wax (Automat Tissue-Tek TEC-5) and sliced with a microtom Reichert-Jung 2030 184 into $4-\mu \mathrm{m}$ thick sections. The sections were stained using a routine hematoxyllin-eosin185 saffron staining method (Automat Sakura DRS601). A representative section of each sample 186 was examined in a double-blind manner by means of light microscopy by one of the ECVP187 pathologists (European college of veterinary pathologists, either authors \#2 and/or \#3 because 188 of the long-term study), but the critical slides were observed by the two pathologists. All 189 lesions were assigned to five main categories recommended for monitoring the biological 190 effects of contaminants in flatfish species: parasitic lesions, inflammations, 191 necrosis/regeneration foci, foci of cellular alteration and neoplasms (Feist et al., 2004). 192 Melano-macrophage aggregates were counted in ten optical fields at high magnification 193 (x400), and only more than 2 aggregates for ten optical fields were considered as an abnormal 194 accumulation. 


\subsection{DNA adduct analysis}

197 The livers of 10 to 15 individuals were pooled, and high molecular weight DNA was

198 extracted using the chloroform/isoamyl alcohol method. Livers were homogenized in $0.8 \mathrm{~mL}$

199 of a solution containing $\mathrm{NaCl}(0.1 \mathrm{M})$, EDTA $(20 \mathrm{mM})$, and Tris-HCl, $\mathrm{pH} 8(50 \mathrm{mM})(\mathrm{SET})$.

200 One hundred $\mu \mathrm{L}$ of SDS (20\%) was added to the homogenate, and following incubation for

$20110 \mathrm{~min}$ at $65^{\circ} \mathrm{C}, 800 \mu \mathrm{L}$ of potassium acetate $(6 \mathrm{M}, \mathrm{pH} 5)$ was added. Then the reaction mixture

202 was kept at $0^{\circ} \mathrm{C}$ for $30 \mathrm{~min}$. After centrifugation for $25 \mathrm{~min}$ at $0^{\circ} \mathrm{C}(10000 \mathrm{~g})$, the supernatant

203 was collected and its nucleic acid content was precipitated overnight at $-20^{\circ} \mathrm{C}$ by adding 2

204 volumes of cold ethanol. DNA pellets were collected, washed once with $1 \mathrm{~mL}$ of $90 \%$ ethanol

205 and dissolved in $500 \mu \mathrm{L}$ of SET $\left(15 \mathrm{~min}\right.$ at $\left.37^{\circ} \mathrm{C}\right)$. The total extract was mixed with $10 \mu \mathrm{L}$ of a

206 mixture of RNase A $(20 \mathrm{mg} / \mathrm{mL})$ and RNase T1 $(10000 \mathrm{U} / \mathrm{mL})$ and incubated for $1 \mathrm{~h}$ at 37

$207{ }^{\circ} \mathrm{C}$; this treatment was repeated twice. Samples were then treated with $20 \mathrm{mg} / \mathrm{mL}$ of

208 proteinase $\mathrm{K}$ for $1 \mathrm{~h}$ at $37^{\circ} \mathrm{C}$. After digestion, $500 \mu \mathrm{L}$ of Rotiphenol was added. The mixture

209 was then moderately shaken for $20 \mathrm{~min}$ at room temperature and centrifuged for $15 \mathrm{~min}$ at

$21015^{\circ} \mathrm{C}(10000 \mathrm{~g})$. The aqueous phase was collected after two extractions. After a final

211 extraction with one volume of chloroform/isoamyl alcohol (24:1), the aqueous phase was

212 collected and $50 \mu \mathrm{L}$ of sodium acetate $(3 \mathrm{M}, \mathrm{pH} 6)$ was added. The DNA was precipitated by

213 the addition of two volumes of cold ethanol overnight at $-20^{\circ} \mathrm{C}$ followed by centrifugation at

$21410000 \mathrm{~g}$ for $30 \mathrm{~min}$. The DNA pellet was washed four times with $90 \%$ ethanol. The purity of

215 the DNA was checked by recording UV spectra between 220 and $320 \mathrm{~nm}$.

216 DNA adducts were measured using the ${ }^{32} \mathrm{P}$-postlabeling method with Nuclease P1 treatment

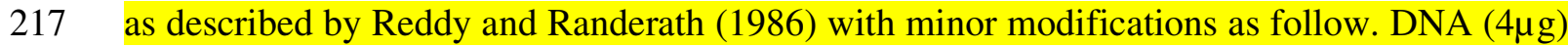

218 was digested at $37^{\circ} \mathrm{C}$ for $4 \mathrm{~h}$ with micrococcal nuclease $(500 \mathrm{mU})$, spleen phosphodiesterase

219 (105mU) buffered with sodium succinate (200mM), and calcium chloride (100mM, pH 6).

220 The digested DNA was then treated with a mixture containing nuclease P1 $(4 \mathrm{mg} / \mathrm{mL}), \mathrm{ZnCl}_{2}$ 
$(1 \mathrm{mM})$ and sodium acetate $(0.5 \mathrm{M}, \mathrm{pH} 5)$ at $37^{\circ} \mathrm{C}$ for $45 \mathrm{~min}$. The reaction was stopped by adding $3 \mu \mathrm{L}$ of Tris base. The DNA adducts were labeled as follows. Five $\mu \mathrm{L}$ of the reaction

\subsection{Statistical analysis}

All statistics were performed with the SAS System release 9.3 (SAS Institute Inc., Cary, NC, USA). Categorical data was tested using a Fisher's exact test or a Cochran-Armitage trend test. Bonferroni's correction was applied for pairwise comparisons. The age and length 
246 relationship was investigated using linear regressions (Proc reg). Logistic regressions were

247 used in order to elucidate the implication of period, season, sex or geographic localization on 248 histological responses (Proc logistic). A p-value below 0.05 was considered as significant.

249

250 3. Results

$251 \quad 3.1 \quad$ Age of the sampled fish

252 Age determination was performed by counting growth rings on otoliths from 87 flounders 253 collected in the Seine estuary. Most collected fish had one to four winters and only 3 out of 87 254 (3.4\%) were much older (Figure 2).

255 In the first three years of fish life (2 winters), a clear age-dependent increase in total body 256 length was observed (Figure 2). For older fish (3 winters and more), body length was no more 257 related to age. In the present study, fish were ranked into four groups according to body 258 length and estimated age. Group 0 included fish up to $110 \mathrm{~mm}$ in length and less than one 259 year old. Group 1 included fish sized 115 up to $200 \mathrm{~mm}$ and aged from one to less than two 260 years old. Group 2 included individuals of 205 up to $300 \mathrm{~mm}$ and aged two to less than three 261 years old. Finally, group 3+ included all fish above $300 \mathrm{~mm}$ with an expected age of three 262 years and more.

263 The different groups were not equally distributed throughout the Seine estuary, with group 0 264 mainly located in the upper Seine estuary, group 1 in the upper and median estuary, group 2 in 265 the median and lower estuary, and finally group 3+ only represented in the lower estuary and 266 in the Seine bay.

267 None of the flounders sampled in the Bay of Veys and in the Ster estuary belonged to group 0. 268 Because of age-structure differences between the three flounder populations, 269 histopathological data from the Bay of Veys and Ster estuary were only used for inter-site 270 comparisons with the Seine estuary. 


\section{$272 \quad 3.2 \quad$ Description of flounder liver pathologies}

273 The liver of the European flounder is composed of parenchymal cells (hepatic cells) and

274 clusters of pancreatic cells along the branches of the portal vein. A hepatic cell has a 275 polygonal body containing a clear spherical nucleus, usually with a single nucleolus. Large

276 quantities of lipids and glycogen are usually observed in the cytoplasm and cause the clear 277 vacuolar appearance of the cell.

278 Lesions, encountered during the liver pathology assessment were categorized into five main 279 items (Figure 3).

280 (i) Encysted parasites (mainly nematodes) are either surrounded by inflammatory cells, that 281 are mainly macrophages forming a granuloma, or only by a thin fibrous capsule (Figure $3 \mathrm{~A}$ ).

282 Depending on the sectioning level, the center of the granuloma and the causative parasite 283 were not always observable (Figure 3B). Less frequently, amoeba infections are associated 284 with ill-delineated foci of necrosis with an influx of macrophages (Figure 3D).

285 (ii) Inflammatory lesions are characterized by the accumulation of inflammatory cells 286 (lymphocytes and macrophages) mainly observed at the vicinity of major blood vessels. 287 Different grades of inflammations were observed, from a few accumulated melano288 macrophage aggregates spread in the liver parenchyma to severe diffuse hepatitis. As the 289 melano-macrophage aggregates can occur under normal conditions in flounder as in other 290 fishes, only more than two aggregates for ten optical fields were considered as an abnormal 291 accumulation (Figure 3C). Diffuse inflammations were very rarely observed and all 292 inflammation types, except host reaction to parasites as described in (i), were jointly recorded. 293 (iii) Foci of necrosis and regeneration (FNR) were jointly recorded because they can both 294 result from cell death following parasitic infestation, bacterial or viral infection and exposure 295 to toxicants. Focal necrosis is characterized by small groups of hepatocytes exhibiting strong 
297 On rare occasions, some foci of small hepatocytes having a high mitosis index formed new 298 trabeculae and were identified as regenerative foci.

299 (iv) Foci of cellular alteration (vacuolated cell foci, clear cell foci, eosinophilic foci, 300 basophilic foci or mixed eosinophilic and basophilic foci) are focal areas exhibiting different 301 staining degrees: some altered staining behaviors can be eosinophilic or basophilic, and some 302 others can be poorly stained (clear cell foci) (Figure 3E, 3F and 3G). These foci do not 303 compress the surrounding parenchyma. Some of these lesions (basophilic foci) are considered 304 as putative pre-neoplastic lesions (Myers et al., 1987).

305 (v) Tumors were identified as hepatocellular or pancreatic, and as adenoma (Figure $3 \mathrm{H}$ ) or 306 adenocarcinoma (Figure 3I). Bile duct tumors were not observed herein. Benign as well as 307 malignant tumors are characterized by cellular atypia associated with architectural 308 abnormalities such as tubular, acinar or solid growth patterns. The tumor growth is associated 309 with a compression (benign) or infiltration (malignant) of the surrounding tissue.

310

311

312 Granulomas with encysted parasites were observed in 8\% (27/338) of sampled flounders in

313 the Seine estuary. Parasite prevalence declined significantly according to age group $(\mathrm{p}<0.001$,

314 Fisher's exact test), with a higher value in group 0 fish $(27 \%)$ than in older ones $(3.7 \%, 7.2 \%$,

$3154.6 \%$ for groups 1, 2, 3+ respectively) (Figure 4A).

316 Nearly $37 \%$ of the sampled flounders (124/338) exhibited liver parenchyma inflammations. 317 Inflammation prevalence significantly differed according to age ( $\mathrm{p}<0.001$, Fisher's exact test) 318 and was globally higher in old fish of three years and more (58.3\%) than in younger ones 319 (22.2 to $32.4 \%)$ (Figure 4A). 
320 Foci of necrosis and regeneration (FNR) were recorded in 5.3\% (18/338) of the sampled

321 flounders. No significant difference was observed according to age group with prevalence

322 varying from $8.1 \%$ for group 0 to $4.6 \%$ for group $3+$ (Figure $4 \mathrm{~A}$ ).

323 More than 6\% (22/338) of all sampled flounders exhibited foci of cellular alteration (FCA).

324 FCA were observed in all groups but with significant prevalence differences according to fish

325 age $(\mathrm{p}<0.05$, Fisher's exact test). Indeed, FCA prevalence was at least three times higher in

326 group $0(18.9 \%)$ than in other groups $(5.6 \%, 5.8 \%$ and $3.7 \%$ for group 1,2 and $3+$

327 respectively) (Figure 4B).

328 Hepatic tumors were recorded in 5 out of 338 flounders (1.5\%). Adenoma occurrences were

329 recorded but no adenocarcinoma was observed. Although not significant, an increasing trend

330 of tumor prevalence was observed with age from $0 \%$ for age groups 0 and 1 to $0.7 \%$ and $3.7 \%$

331 for groups 2 and $3+$ respectively (Figure 4B).

332

333

3.4 Prevalence of flounder liver pathologies according to gender in the Seine estuary

334 Prevalence of parasitic infestations, inflammations and FNR did not vary significantly 335 according to sex (Figure 5A). Although the differences were not significant, FCA were 2.5

336 times more frequent in females $(6.5 \%)$ than in males $(2.6 \%)$ and tumors were only observed 337 in females $(3.0 \%$ ) (Figure 5B). Moreover, when FCA and tumors were scored together, 338 females appeared significantly more affected $(9.5 \%)$ than males $(2.6 \%)(\mathrm{p}<0.05$, Fisher's 339 exact test).

340

341

\subsection{Spatial distribution of flounder liver pathologies in the Seine estuary}

342 Prevalence of parasitic infestation was significantly different $(\mathrm{p}<0.001$, Fisher's exact test) 343 according to the sampling sites (Table 2). Indeed, the infestation prevalence that was recorded 
344 in flounders from the upper part of the Seine estuary (18.4\%) was significantly higher than in

345 fish collected in the median Seine estuary (2.2\%) or Antifer (2.3\%). In contrast, prevalence of

346 inflammations, FNR and tumor did not show any spatial difference. Although FCA frequency

347 was particularly high in flounders from the upper Seine estuary (14.3\%), no statistical

348 difference was observed between the different sampling sites.

349

350

\subsection{Seasonal variations of flounder liver pathologies in the Seine estuary}

351 Since flounders were sampled all the year round in the Seine estuary, it was possible to 352 analyze the seasonal variations of flounder liver pathologies. No significant seasonal variation 353 was observed for FCA, tumors, parasitic infestations and inflammations. Only FNR ( $<<0.05$, 354 Fisher's exact test) did show seasonal fluctuations (Figure 6A and 6B). In flounders from the 355 Seine estuary, FNR occurred more frequently in the summer (11.3\%) than in spring (1.0\%) 356 (Fisher's exact test, $\mathrm{p}=0,004)$.

\subsection{Temporal evolution of flounder liver pathologies in the Seine estuary}

359 The epidemiological survey of liver pathologies was conducted for all the sampled sites, 360 except for the lower Seine estuary, over two distinct periods in 1996-1997 and four years later 361 in 2002-2003. Comparisons of liver pathology profiles between the two sampling periods 362 showed significant differences, including for the 2002-2003 period, a 4-fold increase in 363 parasitic infestations $(\mathrm{p}<0.01$, Fisher's exact test), a 2-fold increase in inflammations 364 ( $\mathrm{p}<0.001$, Fisher's exact test $)$ and a 5-fold increase in FCA $(\mathrm{p}<0.01$, Fisher's exact test $)$ 365 (Figure 7A and 7B). In contrast, FNR occurrence did not vary significantly over the two 366 sampling periods ( $\mathrm{p} \geq 0.05$, Fisher's exact test). For tumor prevalence, the temporal decrease 
367 was almost significant ( $\mathrm{p}=0.06$, Fisher's exact test) with $3.4 \%$ of flounders exhibiting liver

368 tumors in 1996-1997 versus 0\% in 2002-2003 (Figure 7B).

369

370

3.8 Comparison of liver pathologies between flounder populations from the three studied

371 estuaries

372 Flounders were sampled over the same period in three estuaries along the French Atlantic

373 coast. An attempt was made to compare the profiles of liver pathologies between the three

374 flounder populations (Table 3). Since the age structure was different in the three studied

375 populations with an underrepresentation of younger fish in the Bay of Veys and Ster estuary,

376 only adult fish of more than 200mm (groups 2 and 3+) were selected for this analysis.

377 Prevalence of parasitic infestations and inflammations was significantly different between the 378 three flounder populations $(\mathrm{p}<0.001$, Fisher's exact test in both cases). When recorded 379 together, tumors and FCA occurrence was also almost significantly different between 380 estuaries ( $\mathrm{p}=0.053$, Fisher's exact test). Prevalence of infestations was significantly higher $381(\mathrm{p}<0.001)$ in the Ster estuary $(37.6 \%)$ in comparison to the Seine estuary $(5.8 \%)$ and the Bay 382 of Veys $(6.5 \%)$. Flounders from the Ster and the Seine populations were more prone $(\mathrm{p}<0.01)$ 383 to liver inflammations (51.8\% and $40.3 \%$ respectively) than individuals from the Bay of Veys $384(15.2 \%)$ (Table 3). Flounders from the Ster and the Seine estuaries in contrast to those from 385 the Bay of Veys exhibited FCA (9.4\% and 4.9\%, respectively) and tumors (1.2 and 2.1\% 386 respectively). For FNR occurrence, no significant difference was noted for the three studied 387 populations.

388

3893.9 Relationship between the different flounder liver pathologies 
390 A strong positive correlation between parasitic infection and inflammation ( $\mathrm{p}<0.001$, Fisher's

391 exact test) and a negative correlation between inflammation and FNR $(\mathrm{p}<0.001$, Fisher' exact

392 test) were observed. In fact $89 \%$ of fish from the Seine estuary bearing encysted parasites also

393 exhibited liver inflammation while only $25 \%$ of fish with FNR also showed inflammation. In

394 contrast, no obvious relationship was noted between the other liver lesions.

395

396

\subsection{DNA adducts in flounder liver}

397 DNA adducts were measured using the ${ }^{32} \mathrm{P}$-postlabelling technique from pooled livers of 398 flounders collected in September 1996 in the Seine estuary and in April 1997 in the Bay of 399 Veys. Due to insufficient data available (two DNA adduct analyses per site), statistical 400 analysis could not be performed. Nevertheless some spatial trends could be observed. Firstly, 401 the total number of DNA adducts varied greatly from $21.1 \pm 8.0 \mathrm{RAL} / 10^{9}$ nucleotides in the 402 Bay of Veys to $149 \pm 38.5 \mathrm{RAP} / 10^{9}$ nucleotides in the upper Seine estuary (Figure 8).

403 Secondly, the DNA adduct profiles were totally different in the Seine estuary and in the Bay 404 of Veys. The total number of individual spots per site varied from 4 up to 13 in the Seine 405 estuary, and reached 43 in the Bay of Veys (Data not shown). In addition, amongst the 43 406 individual spots detected in the fish from the Bay of Veys, only 18 (42\%) were shared with 407 flounders from the Seine estuary. Finally, most of the adducts (65 to 82\% of RAL) detected in 408 flounders from the Seine estuary were located within the diagonal radioactive zone (DRZ) 409 (Figure 9) while all the DNA adducts detected in flounders from the Bay of Veys were 410 located outside the DRZ (Data not shown).

411 Some spatial trends can also be noted for the Seine estuary. A 10-fold decrease of total DNA 412 adducts in fish liver was observed between the upper Seine estuary and Antifer (Figure 8).

413 The total number of individual adducts declined from 13 spots in the upper Seine estuary to 4 
414 spots in the lower estuary and in Antifer, and no DRZ DNA adducts was detected in Antifer 415 (Figure 9).

416

4174 Discussion

418 In the present paper, pattern and occurrence of liver pathologies were investigated in 419 European flounders from the Seine estuary and from two other reference estuaries on the 420 French Atlantic coast. Implications of various biotic (age, sex) and abiotic (year, season, 421 location) factors in the onset of the different liver pathologies were investigated. Liver DNA 422 adduct levels were also measured to evaluate fish exposure to genotoxic pollutants.

\subsection{Infectious and parasitic diseases}

The most prevalent lesion type was inflammation of liver parenchyma, observed in nearly $37 \%$ of the sampled fish. Inflammation foci and melano-macrophage aggregates were jointly recorded. Both lesions can be induced by multiple stress factors, including at least infectious and parasitic diseases and toxicant exposure (Wolf and Wolfe, 2005). This lesion type was more frequent in older fish but no sex-specific difference was observed. Vethaak and Wester did not show any relationship with fish gender or age (Vethaak and Wester, 1996). This apparent discrepancy could at least partially be explained by the fact that in the latter study only fish with a total length of $200 \mathrm{~mm}$ or more, i.e. only fish of two winters or more were examined (Vethaak and Wester, 1996). In the present study, inflammations were slightly more

434 frequently observed in late winter. Wethaak and Wester (1996) reported the same pattern with 435 a higher occurrence of inflammatory lesions, including parasitic cysts, at the end of winter in 436 flounders captured in spawning grounds. The authors hypothesized that poor conditions and 437 spawning stress could favor bacterial and/or parasite infections. 
438 A clear site-specific profile was also reported with a higher prevalence of inflammatory

439 lesions in individuals from the Ster estuary than in those from the Seine estuary or the Bay of

440 Veys. Previous studies had already documented considerable variations of inflammation 441 occurrence according to geographical area and sampling period from about $12 \%$ in Dutch

442 coastal and estuarine waters (Vethaak and Wester, 1996) to 30\% in coastal areas of the Baltic 443 sea (Lang et al., 2006) (Table 4).

444 The second most prevalent lesion type was the encysted parasite lesion observed in $13 \%$ of all 445 sampled flounders ( $8 \%$ in the Seine estuary). Only a few studies have reported parasitic cysts 446 in flounder liver (Vethaak, 1992; Vethaak and Wester, 1996; Lang et al., 2006; Dezfuli et al., 447 2007). At least one larval and five adult nematode species have already been identified in 448 flounders (El-Darsh and Whitfield, 1999). In contrast to inflammatory lesions, parasitic cysts 449 occurred with a higher prevalence in flounders of group 0 . This feature could putatively be 450 explained by an age-dependent sensitivity of European flounder to nematode infestation and 451 also by heterogeneous spatial distribution of the parasite in favor of the oligohaline or 452 mesohaline part of the estuary. Significant spatial and temporal differences were also 453 evidenced with a similar distribution pattern to that of liver inflammations. Indeed, prevalence 454 of parasitic cysts was higher in the Ster estuary than in the Seine estuary or the Bay of Veys. 455 Moreover, encysted parasite prevalence was slightly higher in flounders collected in late 456 winter.

457 The higher frequency of inflammatory lesions and parasitic cysts in the flounder population 458 inhabiting the Ster is probably not related to a significant chemical stress because pollutant 459 inputs in this estuary are low (Marchand et al., 2003,2004). This result could more likely be 460 explained by the localization of this estuary in the southern part of the flounder distribution 461 area and by a possible thermal stress. This thermal stress could directly affect the immune 462 system or the global health condition of the fish, leading to an increased sensitivity to 
463 infectious agents or parasites. It is noteworthy that relatively high frequencies of flounder

464 liver lesions were detected in the Gulf of Biscay, as compared to English coasts and the North

465 Sea (Laroche et al., 2012).

466

467

\subsection{Toxicopathic liver lesions}

468 Necrosis and regeneration foci were observed in $4.2 \%$ of the sampled fish $(5.3 \%$ in the Seine

469 estuary). No significant difference according to age or gender was observed. This lesion type

470 did not show any significant inter-site variations within the Seine estuary or between the three

471 studied estuaries. In contrast, a clear seasonality was observed with a drastic increase in FNR

472 prevalence in the summer. Seasonal variations of hepatocellular necrosis have already been

473 documented for winter flounders (Pleuronectes americanus) sampled along the US Northeast

474 coast (Johnson et al., 1993). Numerous man-made chemicals are known to induce necrotic

475 lesions in the liver of fish but naturally-occurring toxins such as microcystins can also be

476 potent hepatotoxic agents (Wolf and Wolfe, 2005). It was recently documented that blooms of

477 the cyanobacteria Microcystis aeruginosa producing the microcystin-LR can occur in

478 estuarine waters in the summer time when surface water temperature is high and the stream

479 flow is low (Lehman et al., 2008). Therefore it cannot be ruled out that the higher occurrence

480 of FNR in the liver of flounders in the summer time could not be due to cyanobacterial

481 blooms.

482 Liver tumors and FCA were observed in $1.3 \%$ and $6.3 \%$ of all sampled fish respectively (1.5

483 and $6.5 \%$ in the Seine estuary respectively). Tumors were restricted to females aged two years

484 and more. The differential sensitivity of male and female flounders as regards liver tumors has

485 already been reported (Koehler, 2004; Vethaak and Wester, 1996). Exposure to carcinogens

486 likely takes place early in the life of flounders when larvae migrate to their estuarine habitats

487 (Koehler, 2004). Since all the collected individuals live in the same habitat and feed on the 
same preys, they are likely exposed to the similar cocktail of carcinogens. Koehler proposed that endogenous factors such as estrogen overproduction during vitellogenesis may explain the higher susceptibility of female flounder to develop liver cancer. Indeed, tumor promotion activity of $17-\beta$-oestradiol had already been demonstrated in several fish species (Nunez et al., 1989, Cooke and Hinton, 1999).

In the present study, adenoma was the predominant tumor type (1.0\%) while adenocarcinoma was only observed in a single flounder $(0.2 \%)$. In fact, flounders bearing malignant tumors are rarely observed in the field (Vethaak and Wester, 1996) likely because of quick death or predation of sick individuals. Tumors and FCA were recorded at similar occurrences in the liver of flounders inhabiting the Seine estuary as well as other estuaries, and coastal areas in the North Sea and Baltic Sea (Table 4). Prevalence was somewhat higher along the German coast and particularly in the Elbe estuary but only fish over $180 \mathrm{~mm}$ were analyzed (Koehler, 2004). It is noteworthy that FCA prevalence in flounders from the Seine estuary was recorded at a higher level in group 0 than in the other age groups. Interestingly, Amara and collaborators (2009) have also reported lower growth (daily otolith increments) and condition factor (Fulton's K) for group 0 flounders from the Seine estuary in comparison to those collected in two clean estuaries of the Eastern English Channel. Group 0 flounders are predominantly located in the oligohaline part of the Seine estuary. It was previously documented that sediments from this area were genotoxic resulting at least partially from a high content of mutagenic and carcinogenic PAHs (Cachot et al., 2006). It was also demonstrated that embryos of Japanese medaka exposed to an organic extract of sediment from the upper Seine estuary had an increased mutation rate and developed FCA and neoplasms (Cachot et al., 2007).

In the present work, DNA adducts were measured at high levels in the liver of juvenile 
513 were located in the DRZ. Several authors have reported that DRZ-related DNA adducts are 514 mainly induced by hydrophobic hydrocarbons including polyaromatic hydrocarbon 515 metabolites (Varanasi et al., 1989; Lyons et al., 1999; 2004). Indeed, DRZ-related DNA 516 adducts have been detected in the liver of fish exposed in controlled laboratory conditions to 517 various hydrophobic genotoxicants, including PAHs (Varanasi et al., 1989; Malmström et al., 518 2000), and numerous field studies have documented a positive relationship between pollutant 519 exposure, notably to PAHs, and DNA adduct levels in fish liver (Varanasi et al., 1989; 520 Ericson et al., 1998; Rose et al., 2000; Shaw and Connell, 2001; Aas et al., 2001; Myers et al., 521 2003). DNA adducts are currently considered as good molecular dosimeters of carcinogenic 522 exposure (Shaw and Connell, 2001) and experimental data supports the role of DNA adducts 523 in the initiation of chemical carcinogenesis (Miller and Miller, 1981).

524 It is thus tempting to build a scenario of exposure for flounders dwelling in the Seine estuary. 525 Juveniles, during their first year of life in the upper Seine estuary, are directly exposed to pro526 genotoxic and carcinogenic pollutants such as PAHs originating from contaminated sediments 527 and benthic preys. Chronic exposure to these compounds induces DNA damage and cytotoxic 528 effects which in turn, trigger structural changes in liver parenchyma, including inflammations, 529 necrosis and FCA. Since tumor development is a long lasting process, liver tumors appear 530 much later (at least two years later) when fish migrate to their marine habitat. Vethaak and 531 collaborators demonstrated through a 3-year mesocosm experiment with flounder juveniles 532 exposed to a contaminated dredged spoil that at least 30 months is needed for hepatocellular 533 adenoma development while FCA can emerge within 6 to 12 months (Vethaak et al., 1996).

534 From this study several conclusions can be drawn regarding the use of flounder as a sentinel 535 species for pollution monitoring in estuarine ecosystems. (i) Flounder juveniles settle in 536 estuaries just after metamorphosis and spend at least their first year of life there. (ii) Group 0 537 flounders exhibit a high susceptibility to pollutants, which was revealed in the present study 
538 by DNA adduct induction and the development of toxicopathic liver lesions including 539 necrosis and FCA. (iii) Tumor development is a long lasting process which does not allow 540 reliable measurement of site-specific pollution. Therefore, the measurement of biochemical 541 and histological markers in flounders from group 0 could represent a valuable approach for 542 pollution biomonitoring and fish health assessment in estuarine areas.

\subsection{Conclusion}

545 It was demonstrated herein that flounder liver lesions show high spatial and temporal 546 variations which can be related to various biotic (age, sex, etc.) and abiotic (season, location, 547 pollution, etc.) risk factors. Interestingly, group 0 flounders inhabiting the upper Seine estuary 548 faced a higher prevalence of encysted parasites, and foci of cellular alteration than older ones 549 living in the lower part of the Seine estuary. This result likely reflects differences in the 550 sensitivity of flounders to parasites, pathogens and chemicals, according to age, but also 551 different levels of stress according to season and location. Because of their high sensitivity to 552 multiple stress factors and to their first-year of growth exclusively in estuarine waters, 553 European flounders from group 0 represent valuable bio-indicators for pollution and fish 554 population health monitoring in estuarine ecosystems.

556 Acknowledgments

557 This study was supported by the Agence de l'Eau Seine-Normandie, the Seine-Aval program 558 and Ifremer. Authors would like to thank the Cellule du Suivi du Littoral Haut Normand 559 (CSLHN, Le Havre) and the crews from the oceanographic vessels Gwen Drez (Ifremer) and 560 Esturial (Irstea) for their technical assistance in fish collection. 


\section{References}

563 Aas E, Beyer J, Jonsson G, Reichert WL, Andersen OK (2001) Evidence of uptake,

564 biotransformation and DNA binding of polyaromatic hydrocarbons in Atlantic cod and

565 corkwing wrasse caught in the vicinity of an aluminium works. Mar Environ Res 52: 213-229

566 Amara R, Selleslagh J, Billon G, Minier C (2009) Growth and condition of 0-group European

567 flounder, Platichthys flesus as indicator of estuarine habitat quality. Hydrobiologia 627: 87-98

568 Amat A, Burgeot T, Castegnaro M, Pfohl-Leszkowicz A (2006) DNA adducts in fish

569 following an oil spill exposure Environ Chem Lett 4: 93-99

570 Beck MW, Heck KL, Jr Able KW, Childers DL, Eggleston DB, Gillanders BM, Halpern B,

571 Hays CG, Hoshino K, Minello TJ, Orth RJ, Sheridan PF, Weinstein MP (2001) The

572 identification, conservation, and management of estuarine and marine nurseries for fish and

573 invertebrates. BioScience 51: 633-641

574 Benejam L, Benito J, García-Berthou E (2010) Decreases in condition and fecundity of 575 freshwater fishes in a highly polluted reservoir. Wat Air Soil Poll 210: 231-242

576 Bogovski S, Lang T, Mellergaard S (1999) Histopathological examinations of liver nodules in 577 flounder (Platichthys flesus L.) from the Baltic Sea. ICES J Mar Sci 56: 148-151

578 Brooks ML, Fleishman E, Brown LR, Lehman PW, Werner I, Scholz N, Mitchelmore C, 579 Lovvorn JR, Johnson, ML, Schlenk D, van Drunick S, Drever, JI, Stoms DM, Parker AE, 580 Dugdale R (2012) Life histories, salinity zones, and sublethal contributions of contaminants to 581 pelagic fish declines illustrated with a case study of San Francisco Estuary, California, USA. 582 Estuaries Coasts 35: 603-621

583 Cachot J, Geffard O, Augagneur S, Lacroix S, Le Menach K, Peluhet L, Couteau J, Denier X, 584 Devier MH, Pottier D, Budzinski H (2006) Evidence of genotoxicity related to high PAH 
585 content of sediments in the upper part of the Seine estuary (Normandy, France). Aquat 586 Toxicol 79: 257-267

587 Cachot J, Law M, Pottier D, Peluhet L, Norris M, Budzinski H, Winn R (2007) 588 Characterization of toxic effects of sediment-associated organic pollutants using the $\lambda$ 589 transgenic medaka. Environ Sci Technol 41: 7830-7836

590 Cailleaud K, Forget-Leray, J, Souissi S, Hilde D, LeMenach K, Budzinski H (2007) Seasonal 591 variations of hydrophobic organic contaminant concentrations in the water-column of the 592 Seine Estuary and their transfer to a planktonic species Eurytemora affinis (Calanoïda, 593 copepoda). Part 1: PCBs and PAHs. Chemosphere $70: 270-280$

594 Cailleaud K, Forget-Leray J, Peluhet L, LeMenach K, Souissi S, Budzinski H (2009) Tidal 595 influence on the distribution of hydrophobic organic contaminants in the Seine Estuary and 596 biomarker responses on the copepod Eurytemora affinis. Environ Poll 157 : 64-71.

597 Cooke JB, Hinton DE (1999) Promotion by $17 \beta$-estradiol and $\beta$-hexachlorocyclohexane of 598 hepatocellular tumors in medaka, Oryzias latipes. Aquat Toxicol 45: 127-145

599 Dezfuli BS, Pironi F, Shinn AP, Manera M, Giari L (2007) Histopathology and ultrastructure 600 of Platichthys flesus naturally infected with Anisakis simplex s.l. larvae (Nematoda: 601 Anisakidae). J Parasitol 93: 1416-1423

602 El-Darsh HEM, Whitfield, PJ (1999) The parasite community infecting flounders, Platichthys 603 flesus, in the tidal Thames. J Helminthol $73: 203-214$

604 Ericson G, Lindesjöö E, Balk L (1998) DNA adducts and histopathological lesions in perch 605 (Perca fluviatilis) and northern pike (Esox lucius) along a polycyclic aromatic hydrocarbon 606 gradient on the Swedish coastline of the Baltic sea. Can J Fish Aquat Sci 55: 815-824 
607 Feist SW, Lang T, Stentiford GD, Köhler A (2004) Biological effects of contaminants: Use of 608 liver pathology of the European flatfish dab (Limanda limanda L.) and flounder (Platichthys 609 flesus L.) for monitoring. ICES Techniques in Marine Environmental Sciences 38

610 Gilliers C, Le Pape O, Désaunay Y, Morin J, Guérault D, Amara R (2006) Are growth and 611 density quantitative indicators of essential fish habitat quality? An application to the common 612 sole Solea solea nursery grounds. Est. Coast Shelf Sci 69: 96-106

613 Harmon SM, Wiley FE (2011) Effects of pollution on freshwater organisms. Wat Environ Res $614 \quad 83: 1733-1788$

615 Harris JRW, Cleary JJ, Valkirs AO (1996) Particle-water partitioning and the role of 616 sediments as a sink and secondary source of TBT : In : Champ MA, Seligman PF (Eds) 617 Organtin. Environmental fate and effects. Chapman \& Hall, London, pp 459-474

618 Harshbarger JC, Clark JB (1990) Epizootiology of neoplasms in bony fish of North America. 619 Sci Total Environ 94: 1-32

620 Hinton DE, Segner H, Braunbeck T (2001) Toxic responses of the liver. In : Schlenk D, 621 Bensen WH (Eds.) Toxicity in marine and freshwater teleosts, Vol 1. Taylor and Francis, 622 London, pp 224-268

623 Hinrichsen D (1998) In : Hinrichsen D (Ed.) Coastal waters of the world. Trends, threats and 624 strategies. Island Press, Washington DC

625 Johnson LL, Stehr CM, Olson OP, Myers MS, Pierce SP, Wigren CA, McCain BB, Varanasi $626 \mathrm{U}$ (1993) Chemical contaminants and hepatic lesions in winter flounder (Pleuronectes 627 americanus) from the Northeast Coast of the United States. Environ Sci Technol 27: 2759$628 \quad 2771$

629 Koehler A (2004) The gender-specific risk to liver toxicity and cancer of flounder 630 (Platichthys flesus L.) at the German Wadden Sea coast. Aquat Toxicol 70: 257-276 
631 Lang T, Wosniok W, Baršiene J, Broeg K, Kopecka J, Parkkonen J (2006) Liver 632 histopathology in Baltic flounder (Platichthys flesus) as indicator of biological effects of 633 contaminants. Mar Pol Bull 53: 488-496

634 Laroche J, Gauthier O, Quiniou L, Devaux A, Bony S, Evrard E, Cachot J, Cherel Y, Larcher 635 T, Riso R, Pichereau V, Devier M-H, Budzinski H (2012) Variation patterns in individual fish 636 responses to chemical stress among estuaries, seasons and genders: the case of the European 637 flounder (Platichthys flesus) in the Bay of Biscay. Environ Sci Pol Res, this issue.

638 Lehman PW, Boyer G, Satchwell M, Waller S (2008) The influence of environmental 639 conditions on the seasonal variation of Microcystis cell density and microcystins 640 concentration in San Francisco Estuary. Hydrobiologia 600: 187-204

641 Lyons BP, Stewart C, Kirby MF (1999) The detection of biomarkers of genotoxin exposure in 642 the European flounder (Platichthys flesus) collected from the River Tyne Estuary. Mutat Res 643 - Genet Toxicol Environ Mutagen $446: 111-119$

644 Lyons BP, Stentiford GD, Green M, Bignell J, Bateman K, Feist SW, Goodsir F, Reynolds 645 WJ, Thain JE (2004) DNA adduct analysis and histopathological biomarkers in European 646 flounder (Platichthys flesus) sampled from UK estuaries. Mutat Res - Fund Mol Mecha 647 Mutagen 552: 177-186

648 Malmström CM, Miettinen S, Bylund G (2000) DNA adducts in liver and leukocytes of 649 flounder (Platichthys flesus) experimentally exposed to benzo[a]pyrene. Aquat Toxicol 48: $650 \quad 177-184$

651 Marchand J, Tanguy A, Laroche J, Quiniou L, Moraga, D (2003) Responses of European 652 flounder Platichthys flesus populations to contamination in different estuaries along the 653 Atlantic coast of France. Mar Ecol Prog Ser 260: 273-284 
654 Marchand J, Quiniou L, Riso R, Thebaut M-T, Laroche J (2004) Physiological cost of 655 tolerance to toxicants in the European flounder Platichthys flesus, along the French Atlantic 656 Coast. Aquat Toxicol 70: 327-343

657 Mearns AJ, Reish DJ, Oshida PS, Ginn T, Rempel-Hester MA (2011) Effects of pollution on 658 marine organisms. Wat Environ Res 83: 1789-1852

659 Miller EC, Miller JA (1981). Mechanisms of chemical carcinogenesis. Cancer Res 47: 10556601064.

661 Minier C, Abarnou A, Jaouen-Madoulet A, Le Guellec A-M, Tutundjian R, Bocquené, G, 662 Leboulenger F (2006) A pollution-monitoring pilot study involving contaminant and 663 biomarker measurements in the Seine Estuary, France, using zebra mussels (Dreissena 664 polymorpha). Environ Toxicol Chem 25: 112-119.

665 Myers MS, Rhodes LD, McCain BB (1987) Pathologic anatomy and patterns of occurrence of 666 hepatic neoplasms, putative preneoplastic lesions, and other idiopathic hepatic conditions in 667 English sole (Parophrys vetulus) from Puget Sound, Washington. J Natl Cancer Inst 78: 333668363

669 Myers MS, Johnson LL, Olson OP, Stehr CM, Horness BH, Collier TK, Mccain BB (1998) 670 Toxicopathic hepatic lesions as biomarkers of chemical contaminant exposure and effects in 671 marine bottom fish species from the Northeast and Pacific Coasts, USA. Mar Poll Bull 37: $92-$ 672113

673 Myers MS, Johnson LL, Collier TK (2003) Establishing the causal relationship between 674 polycyclic aromatic hydrocarbon (PAH) exposure and hepatic neoplasms and neoplasia675 related liver lesions in English sole (Pleuronectes vetulus). Human and Ecological Risk 676 Assessment $9: 67-94$ 
677 Nunez O, Hendricks JD, Arbogast DN, Fong AT, Lee BC Bailey GS, (1989) Promotion of 678 aflatoxin B1 hepatocarcinogenesis in rainbow trout by $17-\beta$-estradiol. Aquat Toxicol 15, 289679302

680 Reddy MV, Randerath K (1986) Nuclease P1-mediated enhancement of sensitivity of ${ }^{32} \mathrm{P}$ 681 postlabeling test for structurally diverse DNA adducts. Carcinogenesis 7:1543-51.

682 Rocher B, Le Goff J, Briand M, Manduzio H, Peluhet L, Gallois J, Devier M-H, Gricourt L, 683 Augagneur S, Budzinski H, Pottier D, Andrée V, Lebailly P, Cachot J (2006) Genotoxicant 684 accumulation and cellular defence activation in bivalves chronically exposed to waterborne 685 contaminants from the Seine River. Aquat Toxicol 79: 65-77

686 Rose WL, French BL, Reichert WL, Faisal M (2000) DNA adducts in hematopoietic tissues 687 and blood of the mummichog (Fundulus heteroclitus) from a creosote-contaminated site in 688 the Elizabeth River, Virginia. Mar Environ Res 50: 581-589

689 SGIMC (2011) Report of the Joint ICES/OSPAR Study Group on Integrated Monitoring of 690 Contaminants and Biological Effects (SGIMC). 14-18 march 2011. Copenhaguen, Denmark, 691 ICES Advisory Committee: ICES CM 2011/ACOM:30.

692 Shaw GR, Connell DW (2001) DNA adducts as a biomarker of polycyclic aromatic 693 hydrocarbon exposure in aquatic organisms: Relationship to carcinogenicity. Biomarkers 6 : $694 \quad 64-71$

695 Stentiford GD, Longshaw M, Lyons BP, Jones G, Green M, Feist SW (2003) 696 Histopathological biomarkers in estuarine fish species for the assessment of biological effects 697 of contaminants. Mar Environ Res 55: 137-159

698 Varanasi U, Reichert WL, Stein JE (1989) ${ }^{32}$ P-postlabeling analysis of DNA adducts in liver 699 of wild English sole (Parophrys vetulus) and winter flounder (Pseudopleuronectes 700 americanus). Cancer Res 49: 1171-1177 
701 Vethaak AD (1992) Diseases of flounder (Platichthys flesus L.) in the Dutch Wadden Sea, 702 and their relation to stress factors. Neth J Sea Res 29: 257-272

703 Vetkaak AD, Wester PW (1996) Diseases of flounder Platichthys flesus in Dutch coastal and 704 estuarine waters, with particular reference to environmental stress factors. II. Liver 705 histopathology. Dis Aqua Org 26: 99-116

706 Vethaak AD, Jol JG, Meijboom A, Eggens ML, Rheinallt TA, Wester PW, Van De Zande T, 707 Bergman A, Dankers N, Ariese F, Baan, RA, Everts, JM, Opperhuizen A, Marquenie JM 708 (1996) Skin and liver diseases induced in flounder (Platichthys flesus) after longterm 709 exposure to contaminated sediments in large-scale mesocosms. Environ Health Perspect 104: $710 \quad 1218-1229$

711 Vethaak AD, Jol JG, Martinez-Gomez C (2011) Effects of cumulative stress on fish health 712 near freshwater outlet sluices into the Sea : a case study (1988-2005) with evidence for a 713 contributing role of chemical contaminants. Integrat Environ Ass Manag 7: 445-458

714 Williams TD, Turan N, Diab AM, Wu H, Mackenzie C, Bartie KL, Hrydziuszko O, Lyons 715 BP, Stentiford Grant D, Herbert JM, Abraham JK, Katsiadaki I., Leaver MJ, Taggart JB, 716 George SG, Viant MR, Chipman KJ, Falcian F (2011) Towards a System Level 717 Understanding of Non-Model Organisms Sampled from the Environment: A Network 718 Biology Approach. PLoS Comput Biol 7: 1-20

719 Wolf J, Wolfe MJ (2005) A brief overview of nonneoplastic hepatic toxicity in fish. Toxicol 720 Pathol 33: 75-85.

721

722 Figure captions 
723 Figure 1: Maps showing the geographical position of the different sampling sites. Localization

724 of the three sampled estuaries (A) and the different sampling areas within the Seine estuary 725 (B).

726 Figure 2: Age-length relationship for European flounder specimens collected in the Seine 727 estuary.

728 Figure 3: Histological presentation of European flounder liver lesions. The liver is composed 729 of parenchymal cells (a cell that has a polygonal body containing a clear spherical nucleus and 730 clear appearance of the cytoplasm) and clusters of pancreatic cells along the branches of the 731 portal vein (large dichromatic cells). (A) Parasitic cyst at the vicinity of a pancreatic islet 732 surrounded by a thin rim of fibrous tissue corresponding to encapsulation (arrow). (B) Two 733 well-delineated granulomata slightly compressing the surrounding liver parenchyma (arrows) 734 are composed of large ill-delineated slightly basophilic mononuclear cells characteristic of 735 macrophages. (C) Melano-macrophagic aggregates: randomly scattered in the liver 736 parenchyma, they are composed of large fainted, rarely pigmented cells without 737 encapsulation. (D) A large focus of liquefactive necrosis with cellular debris and numerous 738 amoeba (not shown at this magnification). (E-G) Alteration foci are observed in the 739 parenchyma without compression and are composed of hepatic cells with modifications of 740 their trabecular organization, their size and their cytoplasmic staining: (E) Vacuolated cell 741 alteration focus, ill-delineated focus made of large macro-vacuolated cells (arrow); (F) 742 eosinophilic alteration focus: well-delineated focus made of hypereosinophilic cells; (G) 743 Small basophilic alteration focus: ill-delineated focus made of small hyperbasophilic cells 744 (arrow). (H) Pancreatic adenoma with papillary organization of tumoral cells, well-delineated, 745 encapsulated and compressing the surrounding area of the pancreatic parenchyma. (I) Large 746 infiltrative hepatocellular carcinoma with tubulo-papillar differentiation and a fibrous stroma, 
747

748

749

750

751

752

753

754

755

756

757

758

759

760

761

762

763

764

765

766

767

768

769

totally replacing liver parenchyma. Hematoxylin-Eosin-Saffron. (A, B, H, I) Bar = $100 \mu \mathrm{m}$;

(C-G) $\mathrm{Bar}=50 \mu \mathrm{m}$.

Figure 4: Prevalence (\%) of liver pathologies in European flounders collected in the Seine estuary according to age group. (A) Parasitic, inflammatory, necrotic and regenerative lesions. (B) Pre-neoplastic and neoplastic lesions. Significant differences between age groups are indicated by different letters ( $\mathrm{p}<0.05$, Fisher's exact test with Bonferroni’s correction).

Figure 5: Profile of liver pathologies in European flounders from the Seine estuary according to gender. (A) Parasitic, inflammatory, necrotic and regenerative lesions. (B) Pre-neoplastic and neoplastic lesions. Significant differences between genders are indicated by different letters ( $\mathrm{p}<0.05$, Fisher's exact test with Bonferroni’s correction).

Figure 6: Seasonal variations of liver pathologies in European flounders from the Seine estuary. (A) Parasitic, inflammatory, necrotic and regenerative lesions. (B) Pre-neoplastic and neoplastic lesions. Significant differences between seasons are indicated by different letters $(\mathrm{p}<0.05$, Fisher's exact test with Bonferroni’s correction).

Figure 7: Temporal evolution of liver pathologies in European flounder from the Seine estuary. (A) Parasitic, inflammatory, necrotic and regenerative lesions. (B) Pre-neoplastic and neoplastic lesions. Significant differences between sampling sites are indicated by different letters ( $\mathrm{p}<0.05$, Fisher's exact test with Bonferroni's correction).

Figure 8: DNA adduct levels in the liver of European flounders collected in the Seine estuary (September and October 1996) and in the Bay of Veys (April 1997). Data are expressed as relative adduct labeling per $10^{9}$ nucleotides (Mean $\pm \mathrm{SD}, \mathrm{N}=2$ )

Figure 9: Representative autoradiograms obtained for European flounders collected in the upper Seine estuary (A) or in Antifer (B). In the first autoradiogram, DNA adducts are 
770 predominantly located within the diagonal radioactive zone (DRZ) while in the second only

771 individual spots outside the DRZ are readily visible. 
A

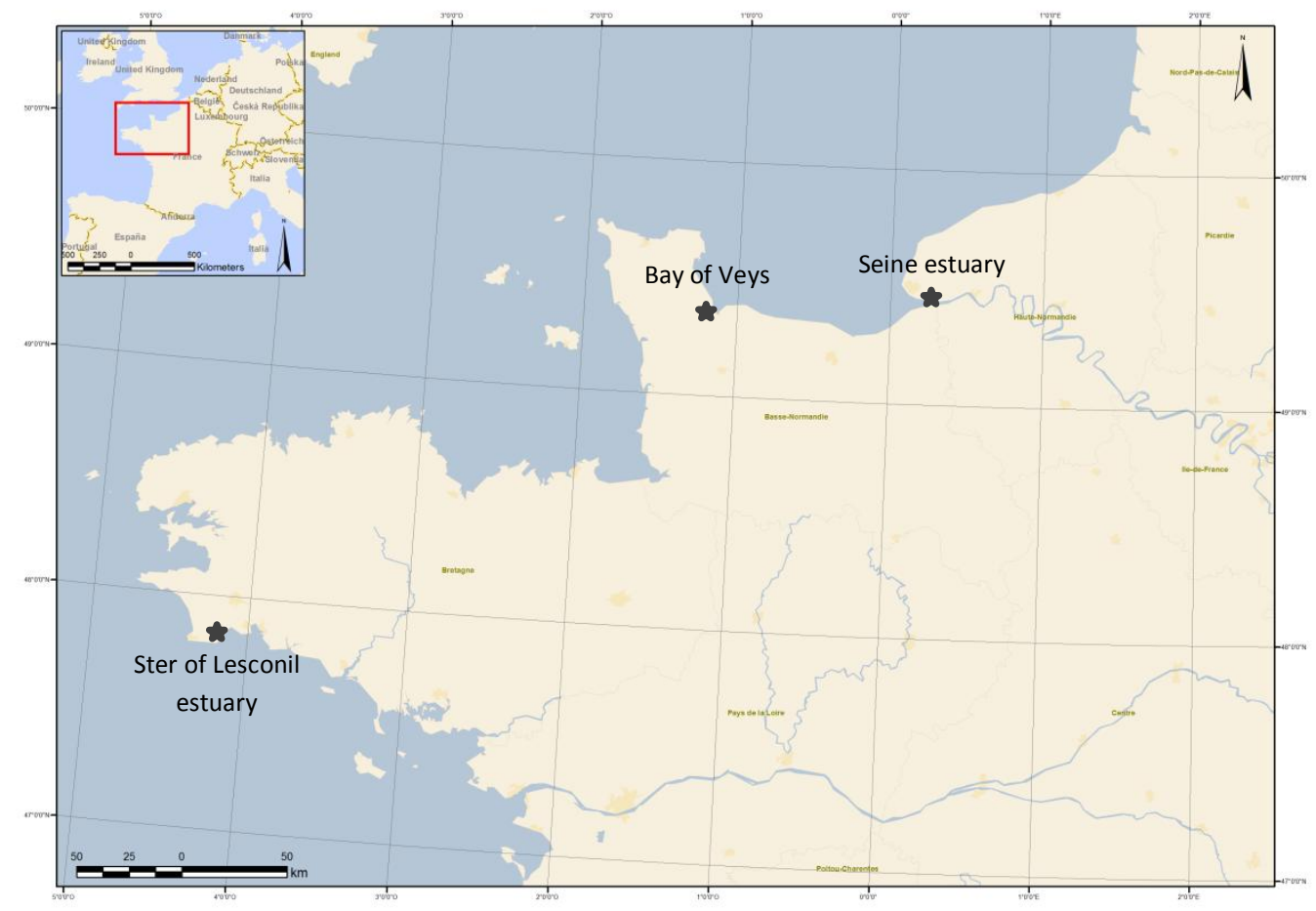

B

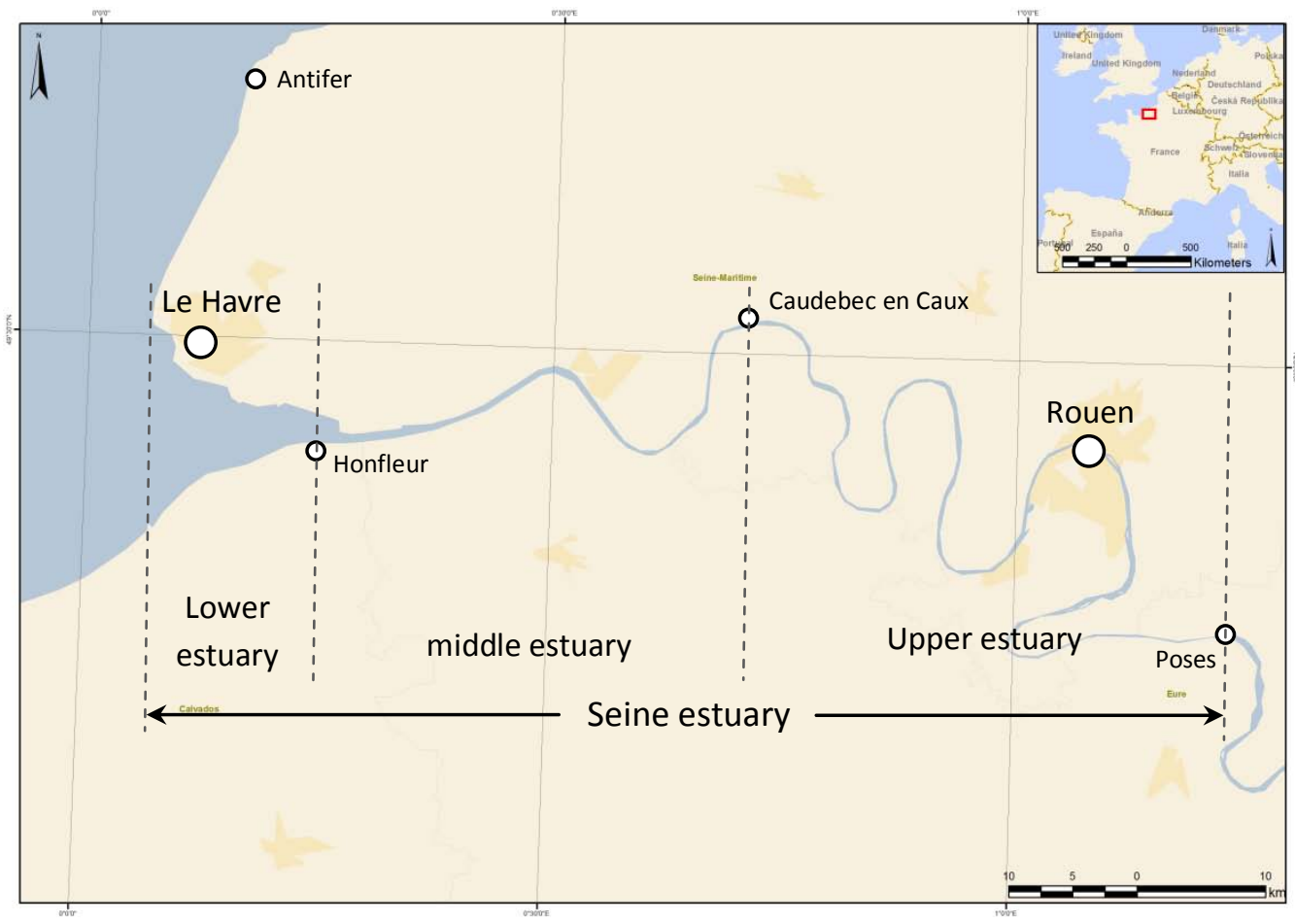




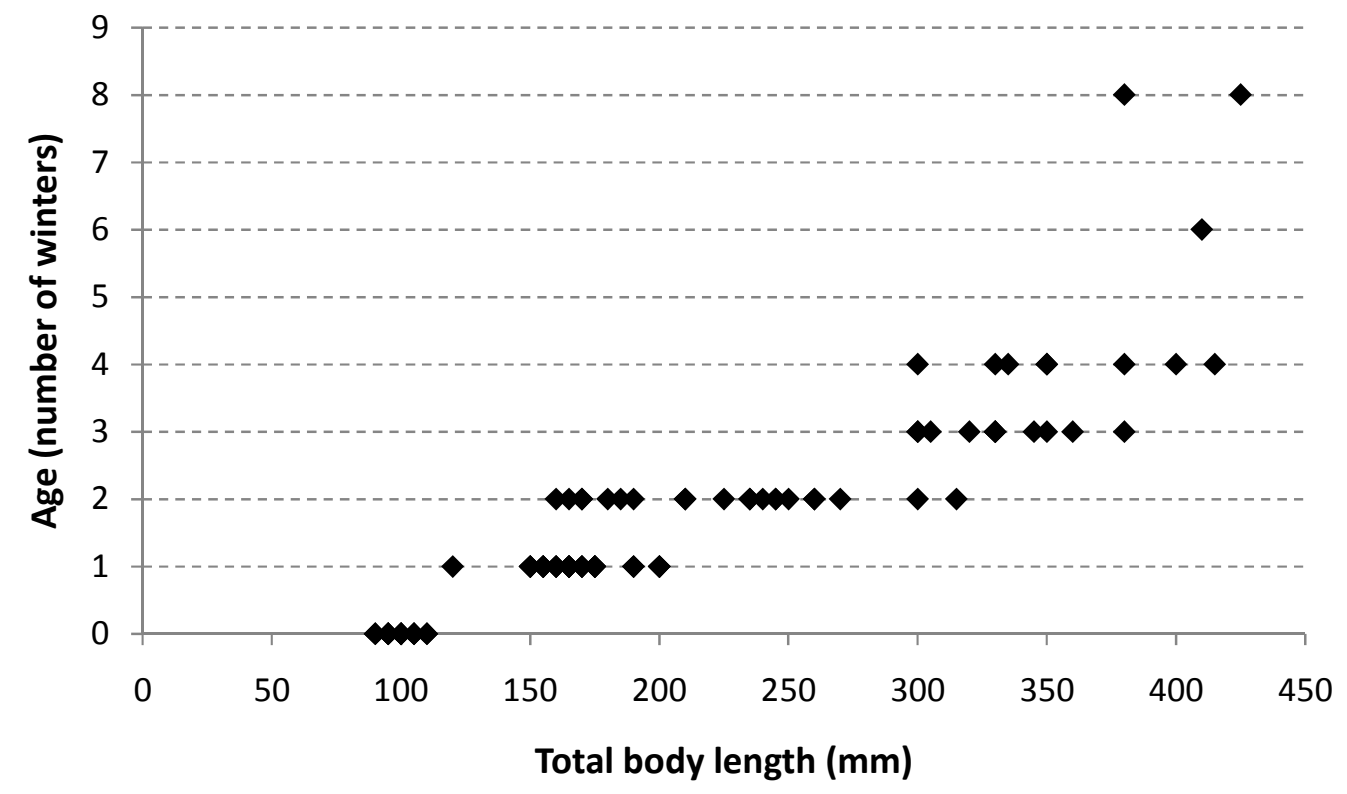

Figure 2

Figure 2

Total body length $(\mathrm{mm})$ 
Figure 3

Figure 3
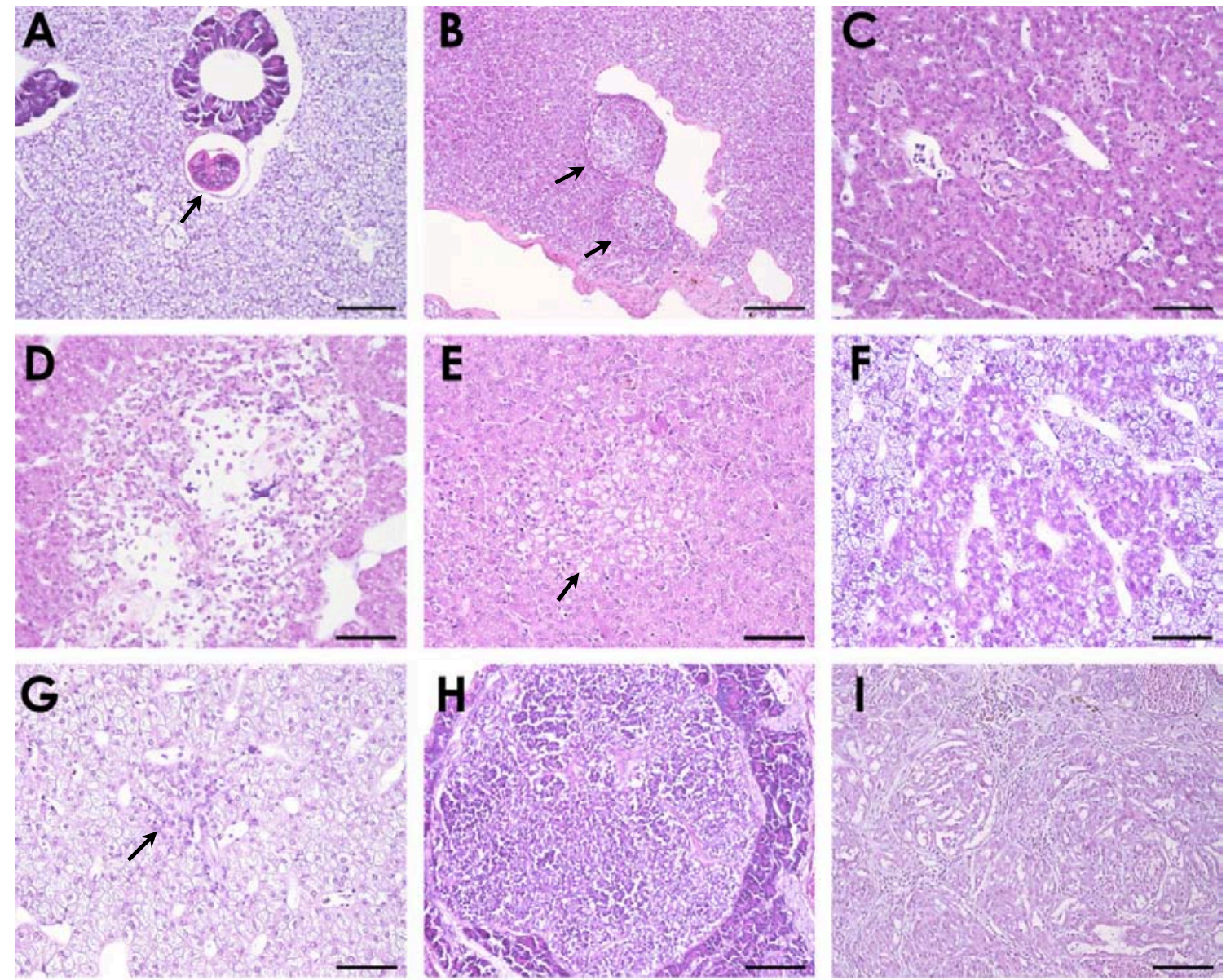
A

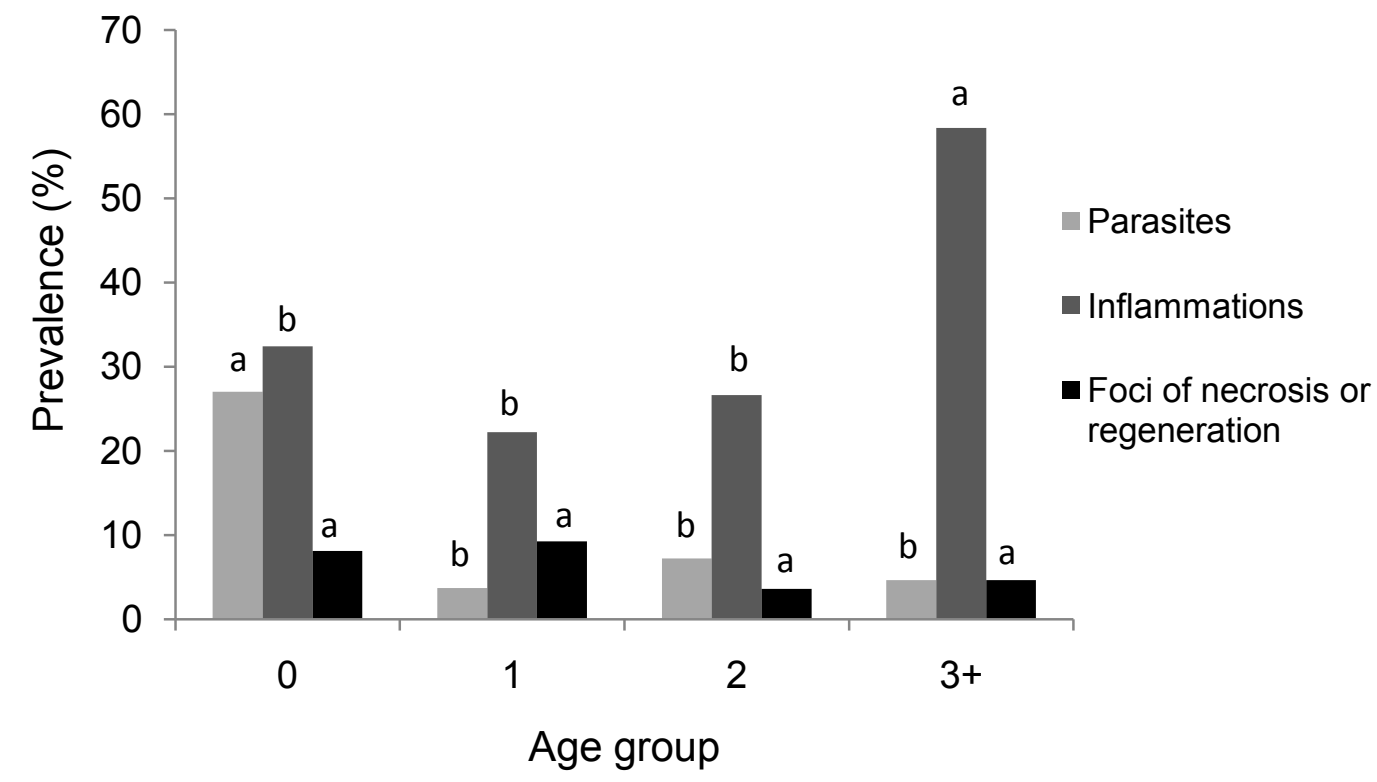

B

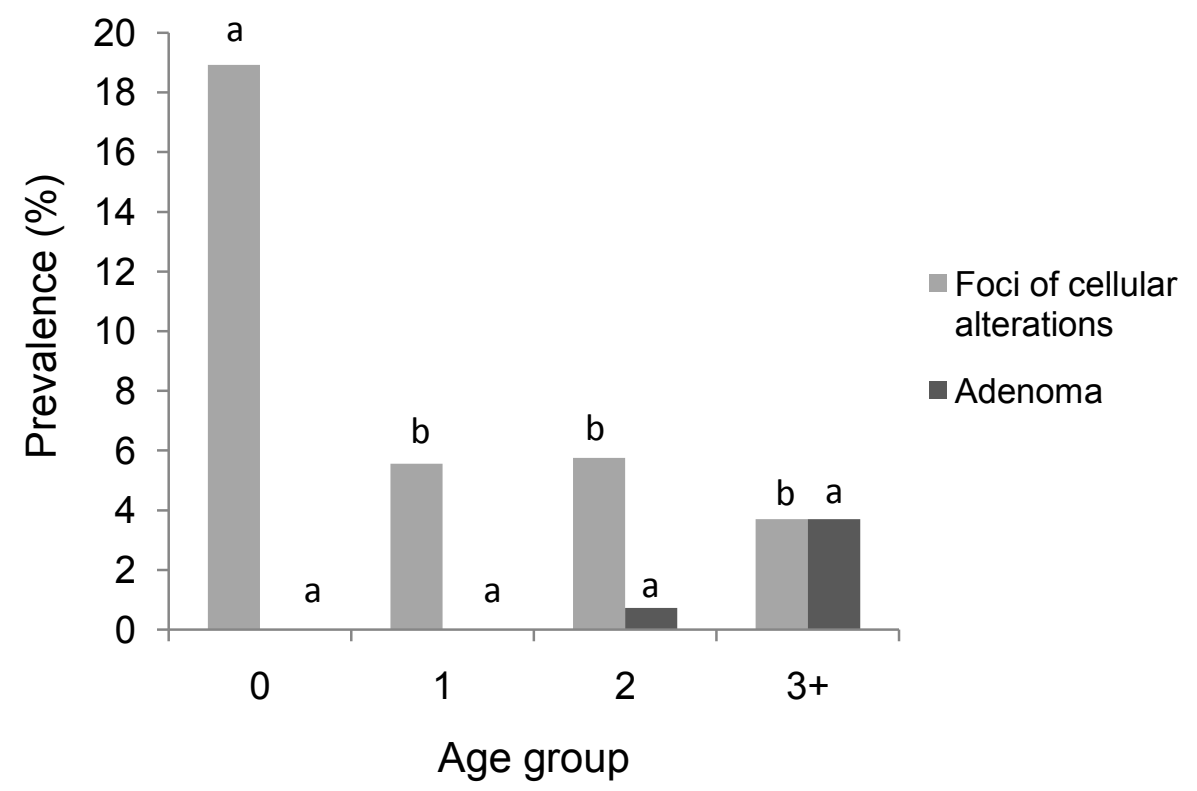

Figure 4 
A

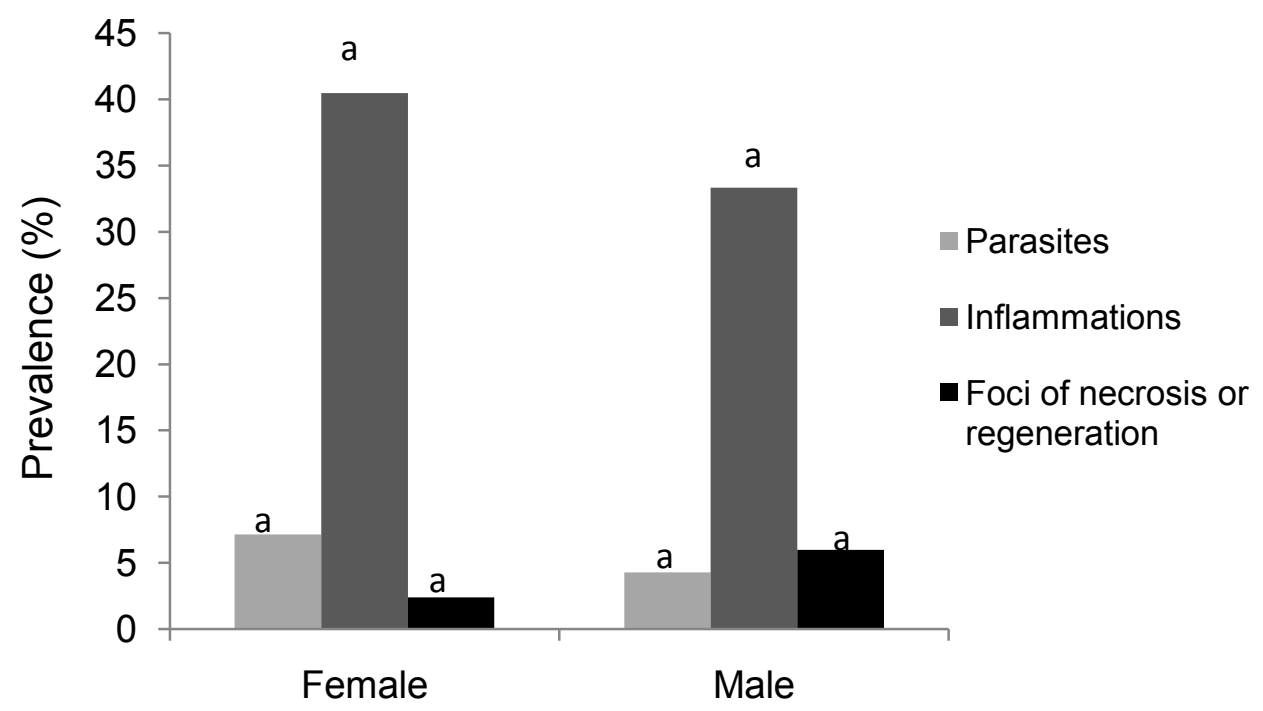

B

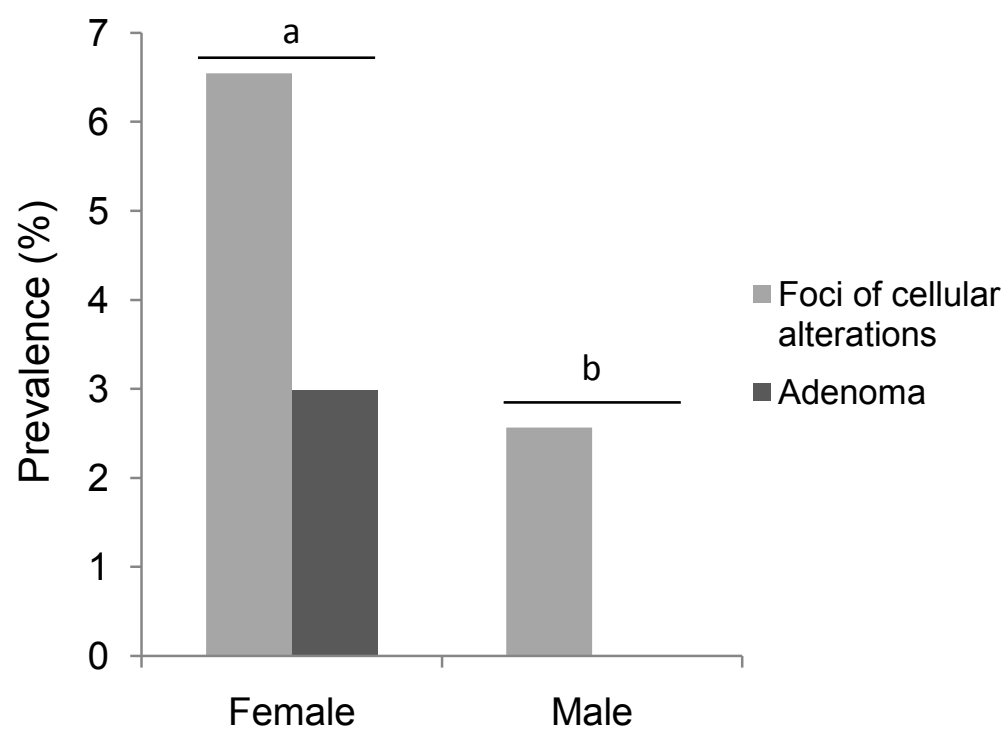

Figure 5 


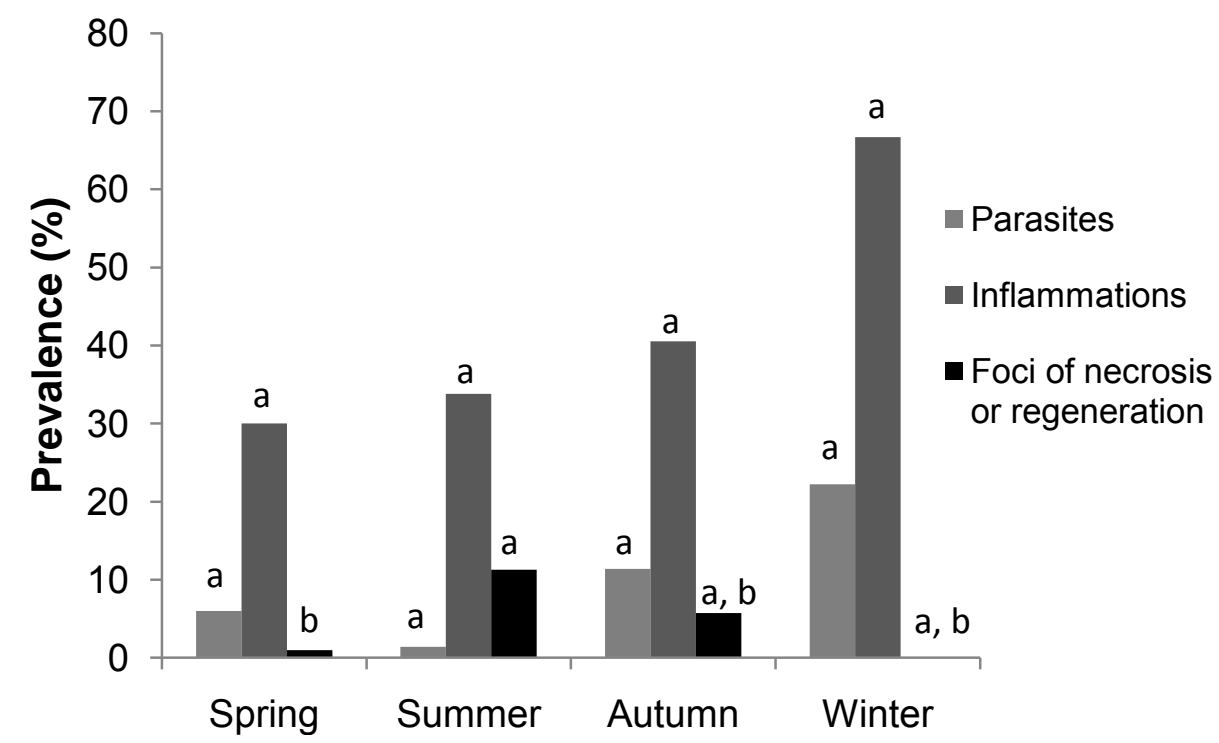

B

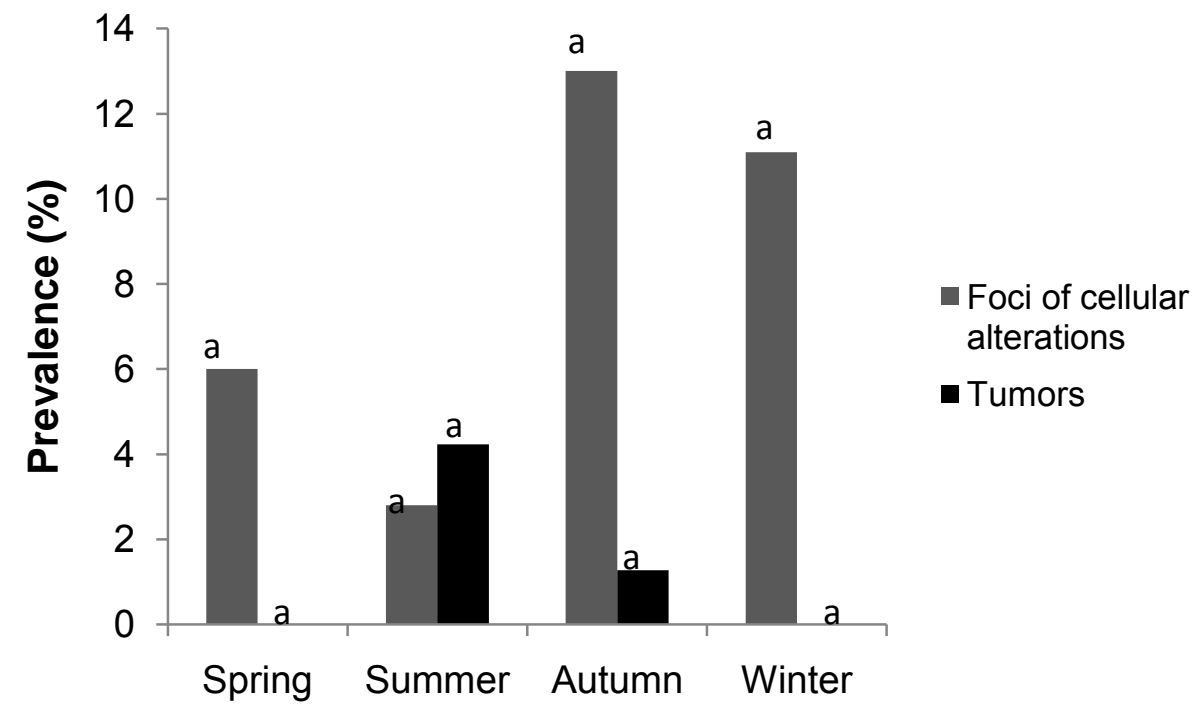

Figure 6 
A

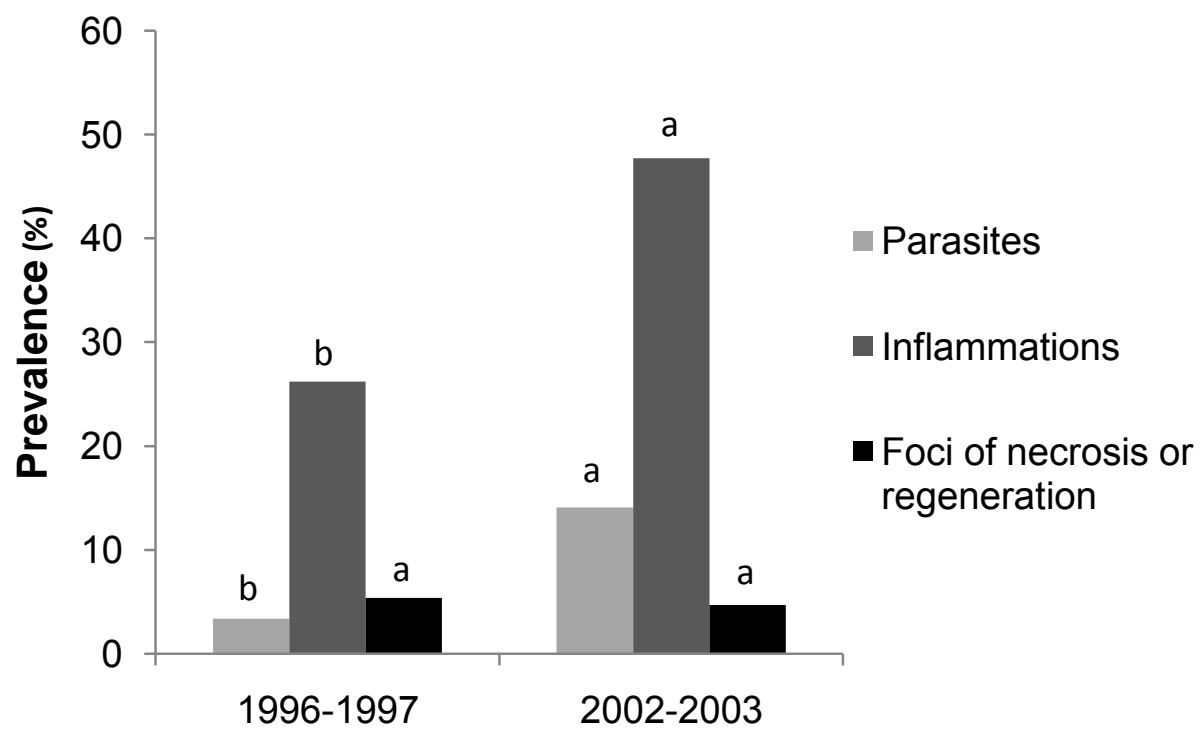

B

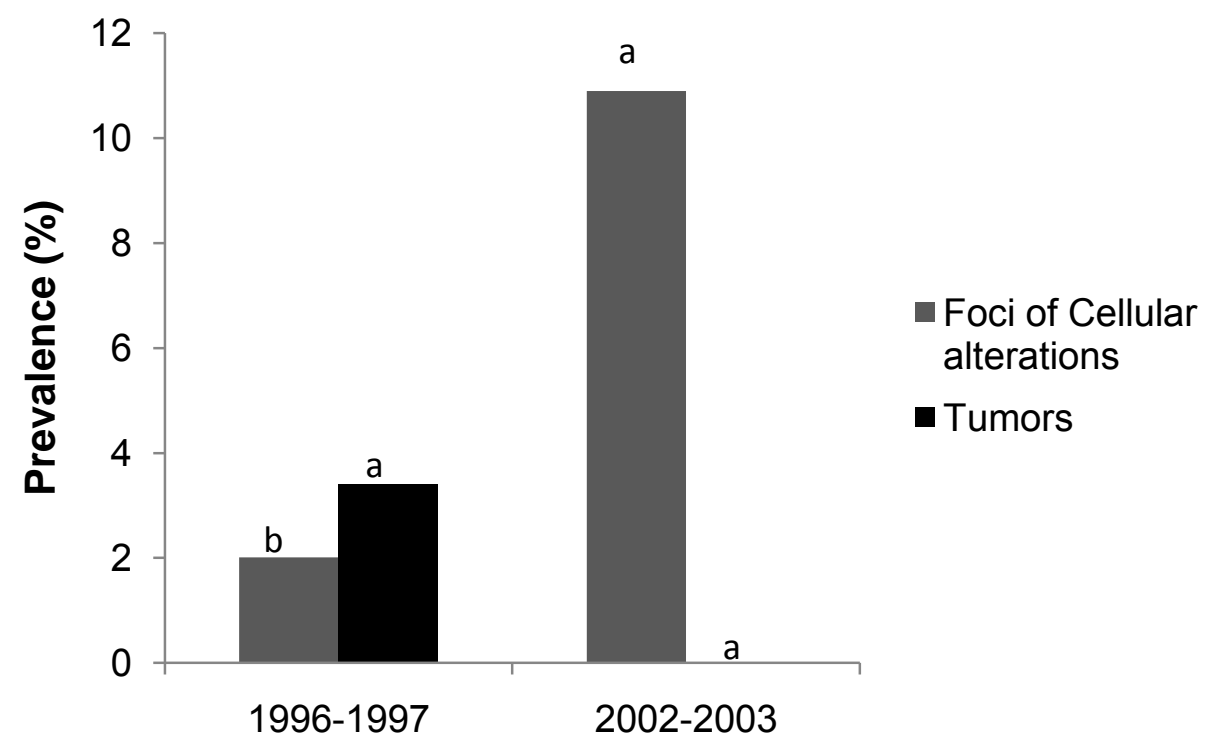

Figure 7 
Figure 8

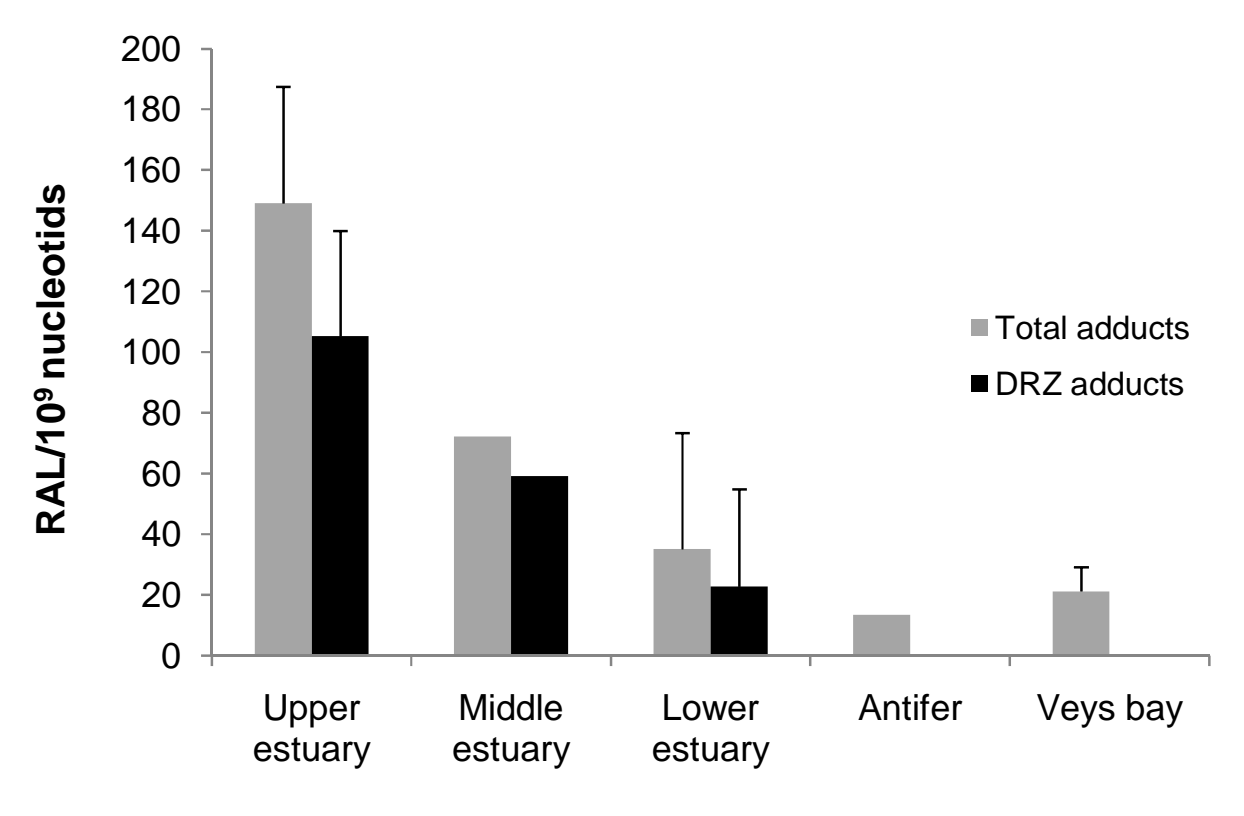

Figure 8

8

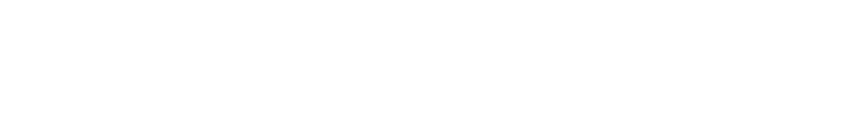

ran

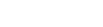

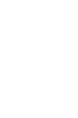

Figure 8 min

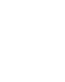
.

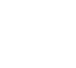

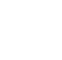

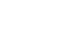
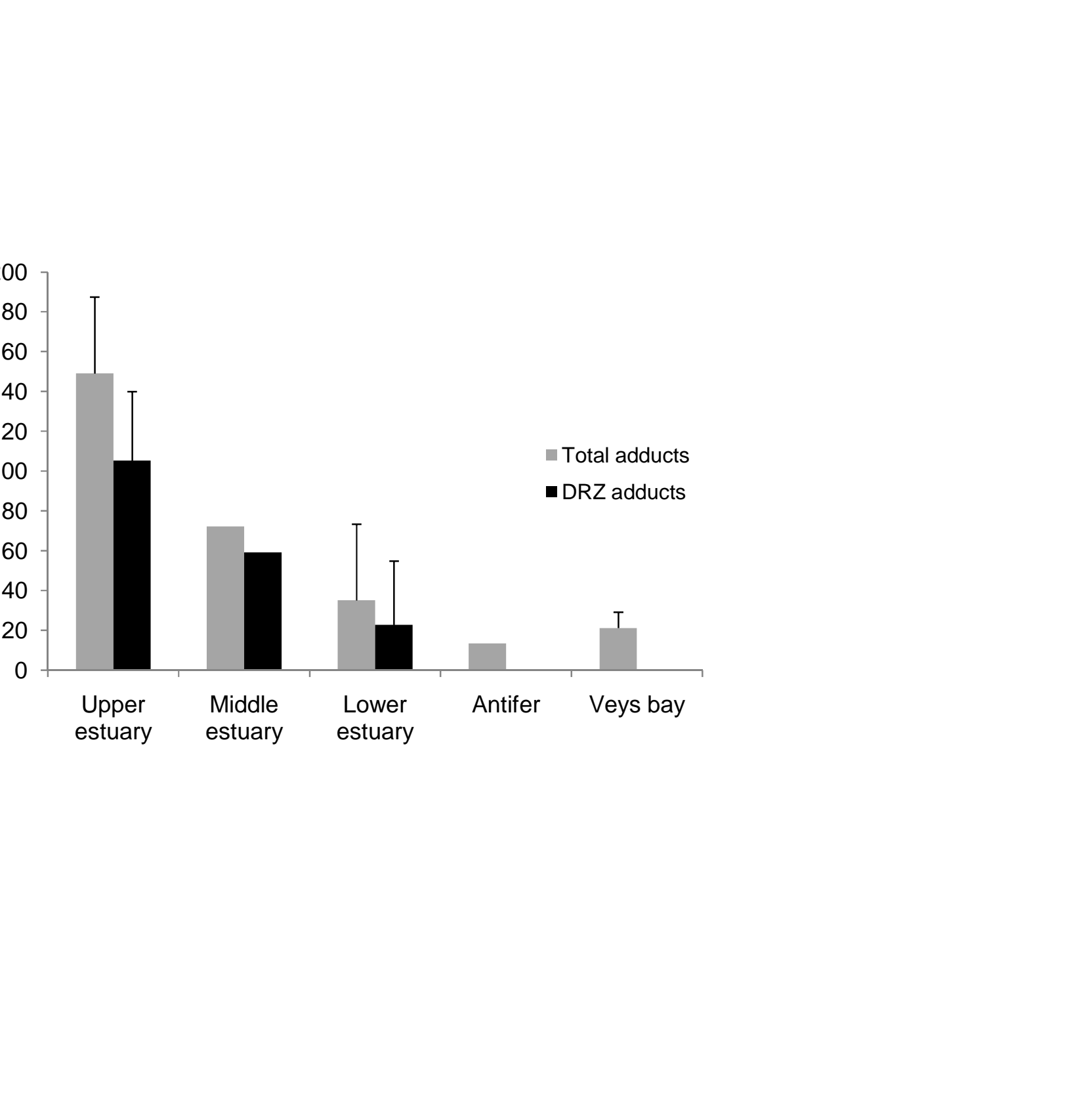

.
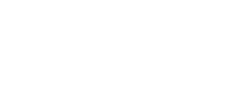
A

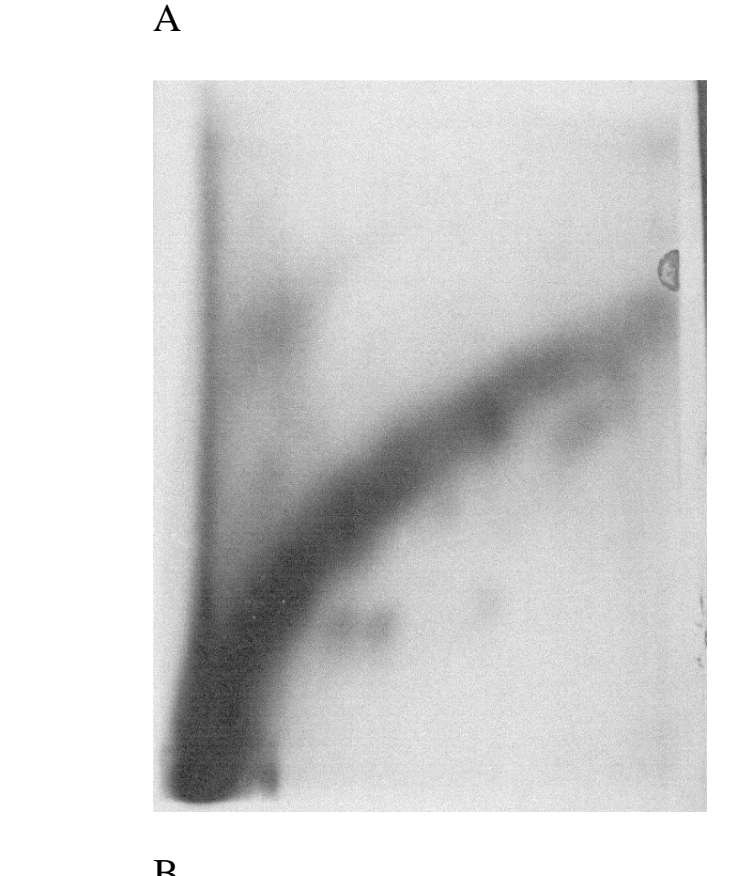

B

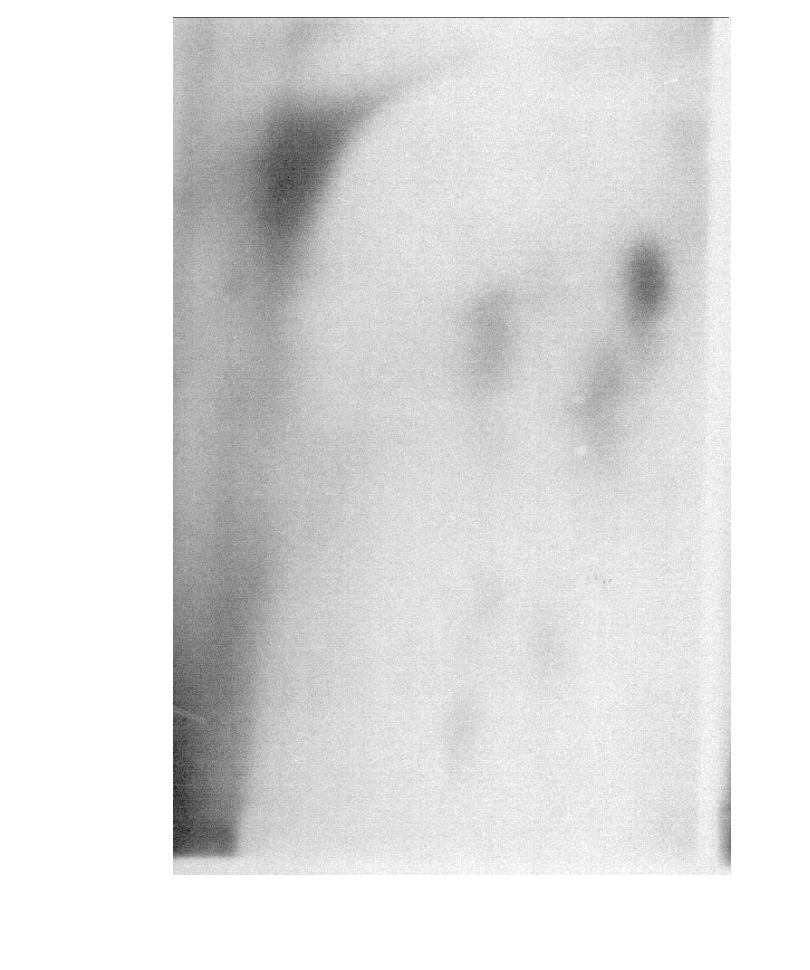

Figure 9

Figure 9

Figure 9

B
(

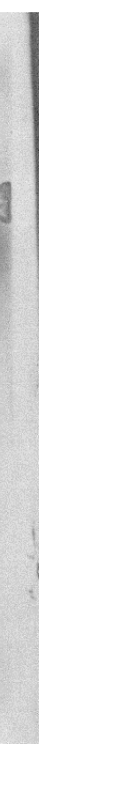

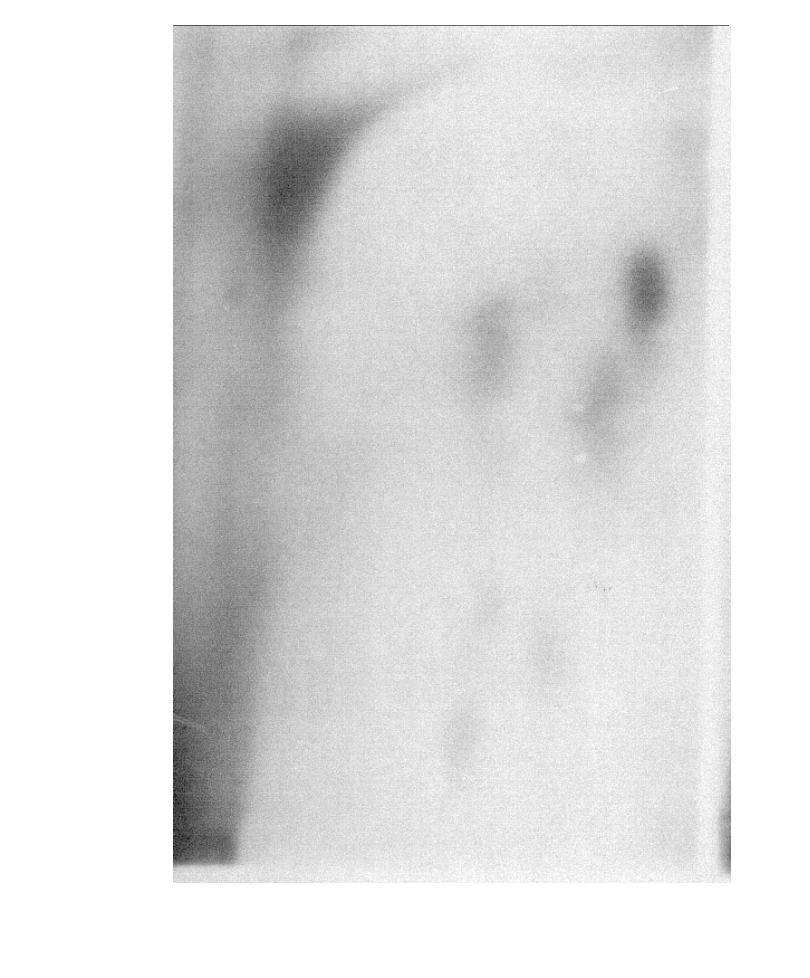

$$
\text { ( }
$$

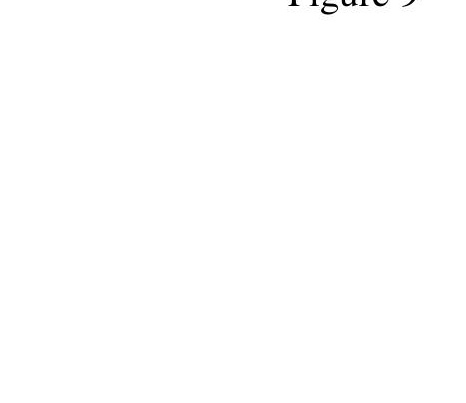


Table 1 : European flounder sampling campaigns in three estuaries from the French Atlantic coast

\begin{tabular}{|c|c|c|c|c|c|}
\hline Sites & $\begin{array}{l}\text { Number de } \\
\text { fishing } \\
\text { campaigns }\end{array}$ & Period & $\begin{array}{l}\text { Number of fish } \\
\text { collected }\end{array}$ & $\begin{array}{l}\text { Sex ratio } \\
\mathrm{M} / \mathrm{F}\end{array}$ & $\begin{array}{l}\text { Total body } \\
\text { length }(\mathrm{cm})\end{array}$ \\
\hline \multirow{10}{*}{$\begin{array}{l}\text { Seine } \\
\text { estuary }\end{array}$} & \multirow[t]{10}{*}{9} & April 1996 & 42 & & \\
\hline & & Sept-Oct 1996 & 101 & & \\
\hline & & March 1997 & 51 & & \\
\hline & & March 2001 & 6 & & \\
\hline & & Sept 2001 & 10 & & \\
\hline & & Feb 2002 & 3 & & \\
\hline & & June 2002 & 23 & & \\
\hline & & Oct-Nov 2002 & 30 & & \\
\hline & & Nov 2003 & 72 & & \\
\hline & & Total & 338 & 0.71 & $4.5-42.5$ \\
\hline \multirow[t]{3}{*}{ Bay of Veys } & \multirow[t]{3}{*}{2} & Sept 1996 & 4 & & \\
\hline & & April-May 1997 & 50 & & \\
\hline & & Total & 54 & 1.41 & $15.5-46$ \\
\hline \multirow[t]{4}{*}{ Ster estuary } & \multirow[t]{4}{*}{3} & May 2002 & 28 & & \\
\hline & & Jan 2003 & 25 & & \\
\hline & & May 2004 & 33 & & \\
\hline & & Total & 86 & 0.36 & $19.5-49.5$ \\
\hline
\end{tabular}


Table 2: Prevalence of liver pathologies in juveniles and adults of European flounder sampled at different locations in the Seine estuary

\begin{tabular}{|c|c|c|c|c|c|c|c|}
\hline & Numbe & & & & & & \\
\hline Sampling sites & of fish & Parasites & Inflammations & FNR & FCA & Adenoma & Carcinoma \\
\hline Upper part & 49 & $18.4 \mathrm{a}$ & $26.5 \mathrm{a}$ & $10.2 \mathrm{a}$ & $14.3 \mathrm{a}$ & $0.0 \mathrm{a}$ & $0.0 \mathrm{a}$ \\
\hline Median part & 45 & $2.2 \mathrm{~b}$ & $26.7 \mathrm{a}$ & $4.4 \mathrm{a}$ & $4.4 \mathrm{a}$ & $0.0 \mathrm{a}$ & $0.0 \mathrm{a}$ \\
\hline Lower part & 157 & $9.5 \mathrm{a}$ & $36.9 \mathrm{a}$ & $3.2 \mathrm{a}$ & $6.4 \mathrm{a}$ & $1.9 \mathrm{a}$ & $0.0 \mathrm{a}$ \\
\hline Antifer & 87 & $2.3 \mathrm{~b}$ & $47.1 \mathrm{a}$ & $6.9 \mathrm{a}$ & $3.4 \mathrm{a}$ & $2.3 \mathrm{a}$ & $0.0 \mathrm{a}$ \\
\hline Seine estuary & 338 & 8.0 & 36.7 & 5.3 & 6.5 & 1.5 & 0.0 \\
\hline
\end{tabular}

FCA : foci of cellular alteration, FNR : foci of necrosis or regeneration

Different letters indicate significant differences between sampling sites (Fisher's exact test with Bonferroni's correction) 
Table 3 : Prevalence of liver pathologies in adults of European flounder (total length > $200 \mathrm{~mm}$ ) from three estuaries from the French Atlantic coast

\begin{tabular}{|c|c|c|c|c|c|c|c|}
\hline Sampling area & $\begin{array}{l}\text { Number } \\
\text { of fish }\end{array}$ & Parasite & Inflammation & FNR & FCA & Adenoma & Carcinoma \\
\hline Bay of Veys & 46 & $6.5 \mathrm{~b}$ & $15.2 \mathrm{~b}$ & $0.0 \mathrm{a}$ & $0.0 \mathrm{a}$ & $0.0 \mathrm{a}$ & $0.0 \mathrm{a}$ \\
\hline Ster estuary & 85 & $37.6 \mathrm{a}$ & $51.8 \mathrm{a}$ & $2.4 \mathrm{a}$ & $9.4 \mathrm{a}$ & $0.0 \mathrm{a}$ & $1.2 \mathrm{a}$ \\
\hline Seine estuary & 243 & $5.8 \mathrm{~b}$ & $40.3 \mathrm{a}$ & $3.7 \mathrm{a}$ & $4.9 \mathrm{a}$ & $2.1 \mathrm{a}$ & $0.0 \mathrm{a}$ \\
\hline Median part & 38 & 2.6 & 28.9 & 0.0 & 5.3 & 0.0 & 0.0 \\
\hline Lower part & 118 & 9.3 & 39.0 & 2.5 & 5.9 & 2.5 & 0.0 \\
\hline Antifer & 87 & 2.3 & 47.1 & 6.9 & 3.5 & 2.3 & 0.0 \\
\hline
\end{tabular}

FCA : foci of cellular alteration, FNR : foci of necrosis or regeneration

Different letters indicate significant differences between sampling sites (Fisher's exact test with Bonferroni's correction) 
Table 4 : Prevalence of liver diseases in European flounders form different geographical areas of the North-east Atlantic

\begin{tabular}{|c|c|c|c|c|c|c|c|c|}
\hline Sampling area & Year & $\begin{array}{l}\text { Number } \\
\text { of fish }\end{array}$ & Parasite & INF & FNR & $\overline{\text { FCA }}$ & Tumor & Reference \\
\hline $\begin{array}{l}\text { Dutch North Sea } \\
\text { coast }\end{array}$ & $\begin{array}{l}1985- \\
1989\end{array}$ & 315 & - & 11.7 & 5.4 & 11.4 & 0.3 & $\begin{array}{l}\text { Vethaak and } \\
\text { Wester, } 1996\end{array}$ \\
\hline $\begin{array}{l}\text { Dutch Wadden } \\
\text { Sea coast }\end{array}$ & 1988 & 9608 & 5.0 & - & - & $<0.1$ & $<0.1$ & Vethaak, 1992 \\
\hline $\begin{array}{l}\text { Dutch Wadden } \\
\text { Sea coast (Den } \\
\text { Oever) }\end{array}$ & 1996 & 240 & - & 12.5 & - & 1.7 & 0 & $\begin{array}{l}\text { Vethaak et al., } \\
2011\end{array}$ \\
\hline $\begin{array}{l}\text { German Wadden } \\
\text { Sea coast }\end{array}$ & $\begin{array}{l}1995- \\
2000\end{array}$ & 1468 & - & - & - & $19-34$ & $4-38$ & Koehler, 2004 \\
\hline Baltic Sea & 1994 & 3008 & - & - & - & 0.6 & 0.9 & $\begin{array}{l}\text { Bogovski et al. } \\
1999\end{array}$ \\
\hline Baltic Sea coast & $\begin{array}{l}2001- \\
2002\end{array}$ & $436 *$ & 17.7 & 28.9 & - & 4.6 & 0.7 & $\begin{array}{l}\text { Lang et al., } \\
2006\end{array}$ \\
\hline UK estuaries & 2000 & 204 & - & 20 & - & 17.6 & 1.5 & $\begin{array}{l}\text { Stentiford et al., } \\
2003\end{array}$ \\
\hline UK estuaries & 2006 & 81 & $0-6$ & $10-67$ & $5-22$ & $0-28$ & $0-11$ & $\begin{array}{l}\text { Williams et al., } \\
2011\end{array}$ \\
\hline Seine estuary & $\begin{array}{l}1996- \\
2003\end{array}$ & 338 & 8.0 & 36.7 & 5.3 & 6.5 & 1.5 & This study \\
\hline
\end{tabular}

INF : inflammation, FCA : Foci of Cellular Alteration, FNR : Foci of Necrosis or Regeneration. (*) Female only 